\title{
Florida Current surface temperature and salinity variability during the last millennium
}

\author{
David C. Lund ${ }^{1,2}$ and William Curry ${ }^{1}$ \\ Received 12 September 2005; revised 23 November 2005; accepted 19 January 2006; published 5 May 2006.
}

[1] The salinity and temperature of the Florida Current are key parameters affecting the transport of heat into the North Atlantic, yet little is known about their variability on centennial timescales. Here we report replicated, high-resolution foraminiferal records of Florida Current surface hydrography for the last millennium from two coring sites, Dry Tortugas and the Great Bahama Bank. The oxygen isotopic composition of Florida Current surface water $\left(\delta^{18} \mathrm{O}_{\mathrm{w}}\right)$ near Dry Tortugas increased $0.4 \%$ during the course of the Little Ice Age (LIA) $\left(\sim 1200_{-}\right.$ 1850 A.D.), equivalent to a salinity increase of $0.8-1.5$. On the Great Bahama Bank, where surface waters are influenced by the North Atlantic subtropical gyre, $\delta^{18} \mathrm{O}_{\mathrm{w}}$ increased by $0.3 \%$ during the last 200 years. Although a portion $\left(\sim 0.1 \%\right.$ o of this shift may be an artifact of anthropogenically driven changes in surface water $\Sigma \mathrm{CO}_{2}$, the remaining $\delta^{18} \mathrm{O}_{\mathrm{w}}$ signal implies a $0.4-1$ increase in salinity after 200 years B.P. The simplest explanation of the $\delta^{18} \mathrm{O}_{\mathrm{w}}$ data is southward migration of the Atlantic Hadley circulation during the LIA. Scaling of the $\delta^{18} \mathrm{O}_{\mathrm{w}}$ records to salinity using the modern low-latitude $\delta^{18} \mathrm{O}_{\mathrm{w}}-\mathrm{S}$ slope produces an unrealistic reversal in the salinity gradient between the two sites. Only if $\delta^{18} \mathrm{O}_{\mathrm{w}}$ is scaled to salinity using a high-latitude $\delta^{18} \mathrm{O}_{\mathrm{w}}$-S slope can the records be reconciled. Variable atmospheric ${ }^{14} \mathrm{C}$ paralleled Dry Tortugas $\delta^{18} \mathrm{O}_{\mathrm{w}}$, suggesting that solar irradiance paced centennial-scale migration of the Inter-Tropical Convergence Zone and changes in Florida Current salinity during the last millennium.

Citation: Lund, D. C., and W. Curry (2006), Florida Current surface temperature and salinity variability during the last millennium, Paleoceanography, 21, PA2009, doi:10.1029/2005PA001218.

\section{Introduction}

[2] The Little Ice Age was the most prominent climate event of the last millennium prior to the 20th century. Historical accounts describe severe cold conditions in Europe and North America at intermittent periods during the LIA [Grove, 1988; Bradley and Jones, 1993] and terrestrial paleoclimate data suggest the LIA was a global phenomenon [Bradley and Jones, 1993; Mann et al., 1999; Esper et al., 2002; Dahl-Jensen et al., 1998; Huang et al., 2000; Thompson, 1995; Chinn, 1996; Denton and Karlén, 1973]. Reconstructions of North Atlantic sea surface temperatures (SSTs) show that the eastern subtropical gyre cooled nearly $4^{\circ} \mathrm{C}$ during the LIA [deMenocal et al., 2000] while the Sargasso Sea cooled by $\sim 1{ }^{\circ} \mathrm{C}$ [Keigwin, 1996]. The western edge of the gyre apparently cooled by $1^{\circ}-3^{\circ} \mathrm{C}$ relative to today during the coldest LIA intervals [Druffel, 1982; Winter et al., 2000]. In both the eastern gyre and Sargasso Sea locations, the LIA was preceded by a relatively warm interval from $\sim 500$ to 1200 A.D., the socalled "Medieval Warm Period".

[3] The Yucatan Peninsula [Hodell et al., 2005] and the Cariaco Basin [Haug et al., 2001] experienced unusually

\footnotetext{
${ }^{1}$ Massachusetts Institute of Technology, Woods Hole Oceanographic Institution Joint Program in Oceanography, Woods Hole, Massachusetts, USA.

${ }^{2}$ Now at Division of Geological and Planetary Sciences, California Institute of Technology, Pasadena, California, USA.
}

Copyright 2006 by the American Geophysical Union. 0883-8305/06/2005PA001218\$12.00 dry Little Ice Age conditions. The records can be interpreted as a southward shift of the Atlantic Inter-Tropical Convergence Zone (ITCZ), either as a result of a greater meridional temperature gradient in the North Atlantic or persistent El Niño-like conditions in the equatorial Pacific [Haug et al., 2001]. Shifts in mean ITCZ position affect evaporation and precipitation in the tropical Atlantic and may act to stabilize perturbations to the Atlantic overturning circulation by influencing Gulf Stream salinity [Vellinga et al., 2002].

[4] Here we present evidence from high-resolution sediment cores that Florida Current salinity increased during the Little Ice Age. The simplest explanation for this pattern is a southward shift of the Atlantic ITCZ and increased evaporation minus precipitation $(\mathrm{E}-\mathrm{P})$ in the tropical Atlantic. These data support the suggestion that southward ITCZ migration caused dry LIA conditions in Central and South America [Haug et al., 2001; Hodell et al., 2005] and are consistent with simulations of increased aridity in the tropical North Atlantic in response to Northern Hemisphere cooling [Vellinga et al., 2002; Lohmann, 2003; Vellinga and $W u, 2004]$. On the eastern edge of the Florida Current, $\delta^{18} \mathrm{O}_{\mathrm{w}}$ was anomalously low during the Little Ice Age, perhaps because of southward movement of the Hadley circulation.

\section{Oceanographic Setting}

[5] We used four sediment cores for this study, two from each side of the Florida Current, the portion of the Gulf 
Stream confined to the Straits of Florida. Cores KNR166-262MC-A and W167-79GGC were retrieved near Dry Tortugas, on the northwestern edge of the Florida Current (Figure 1). Cores KNR166-2-118MC-A and KNR166-2125MC-D were retrieved from the Great Bahama Bank, on the eastern edge of Florida Current. Although separated in distance by only $400 \mathrm{~km}$, the surface water at each location represents distinct oceanographic regimes. On the western side of the Florida Current, surface water is fresh because of to the advection of low-salinity waters from the tropical Atlantic [Schmitz and Richardson, 1991]. Today, tropical Atlantic and Caribbean surface salinity is controlled largely by the excess rainfall relative to evaporation under the ascending branch of the Hadley circulation, the ITCZ. Rainfall associated with the annual migration of the ITCZ between $5^{\circ} \mathrm{S}$ and $15^{\circ} \mathrm{N}$ [Waliser and Gautier, 1993] is the primary reason surface water salinity is low in this region (Figure 1). This water is advected through the Caribbean and into the Straits of Florida via prevailing wind-driven and meridional overturning transports. Annual average salinity near Dry Tortugas is 36.1 with a seasonal and interannual range of approximately \pm 0.1 and \pm 0.2 , respectively (J. A. Carton and B. S. Giese, SODA: A reanalysis of ocean climate, unpublished manuscript, 2006, available at http://www. atmos.umd.edu/\%7Ecarton/pdfs/carton-giese06. pdf, hereinafter referred to as Carton and Giese, 2006).

[6] The Great Bahama Bank core sites reflect the influence of both the Florida Current and the Santaren Current, which is relatively salty because of the influence of the subtropical gyre. Higher salinities in the subtropical gyre reflect positive $\mathrm{E}-\mathrm{P}$ conditions that occur under the dry, descending branch of the Hadley circulation and the convergence of surface water because of Ekman transports. Annual average salinity near the $118 \mathrm{MC}$ and $125 \mathrm{MC}$ core sites is 36.2 (Carton and Giese, 2006). The seasonal and interannual range in salinity is approximately \pm 0.05 and \pm 0.15 , respectively (Carton and Giese, 2006), somewhat smaller than the Dry Tortugas region.

\section{Methods and Core Top Results}

[7] The hydrographic reconstructions presented here are based on paired measurements of oxygen isotopes and $\mathrm{Mg} / \mathrm{Ca}$ in fossil shells of planktonic foraminifera. The $\delta^{18} \mathrm{O}$ of calcite $\left(\delta^{18} \mathrm{O}_{c}\right)$ precipitated by foraminifera is a function of temperature (T) and $\delta^{18} \mathrm{O}$ of the seawater $\left(\delta^{18} \mathrm{O}_{\mathrm{w}}\right)$. By using paired measurements of oxygen isotopic composition $\left[\delta^{18} \mathrm{O}_{\mathrm{c}} \approx f\left(\mathrm{~T}, \delta^{18} \mathrm{O}_{\mathrm{w}}\right)\right]$ and magnesium concentration $[\mathrm{Mg} / \mathrm{Ca} \approx f(\mathrm{~T})]$, it is possible to estimate $\delta^{18} \mathrm{O}_{\mathrm{w}}$, which is related to salinity through evaporation and precipitation at the ocean surface [Mashiotta et al., 1999]. We measured $\delta^{18} \mathrm{O}_{\mathrm{c}}$ and $\mathrm{Mg} / \mathrm{Ca}$ in the surface dwelling foraminifer Globigerinoides ruber in cores from each side of the Florida Current to reconstruct salinity variability over the last millennium.

\subsection{Age Control}

[8] Down-core age control is based on multiple planktonic foraminiferal radiocarbon dates in each core (Table 1). Each date is based on an average of $8 \mathrm{mg} \mathrm{G}$. ruber speci-
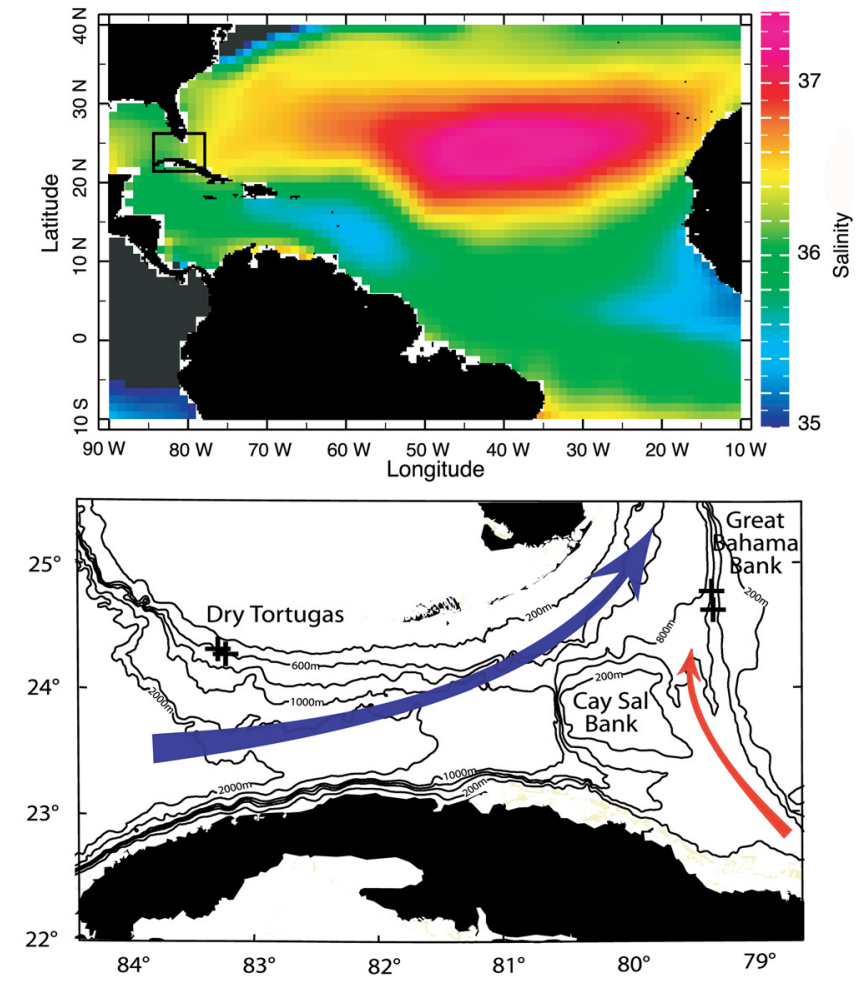

Figure 1. (top) Map of North Atlantic annual average salinity at $30 \mathrm{~m}$ depth [Levitus et al., 1994]. High subtropical gyre salinities $(>36)$ reflect positive evaporation minus precipitation (E-P) under the descending limb of the Hadley circulation, while low tropical North Atlantic salinities $(<36)$ reflect negative $\mathrm{E}-\mathrm{P}$ under the Inter-Tropical Convergence Zone. Inset rectangular box represents the region addressed in this study. (bottom) Bathymetric map of study region (200-m contour intervals). The Dry Tortugas sites (plus signs), 62MC (547 m depth; $\left.24^{\circ} 19.6^{\prime} \mathrm{N}, 83^{\circ} 15.4^{\prime} \mathrm{W}\right)$ and 79 GGC $\left(530 \mathrm{~m}\right.$ depth; $\left.24^{\circ} 21.5^{\prime} \mathrm{N}, 83^{\circ} 20.9^{\prime} \mathrm{W}\right)$, sit on the northwestern edge of the Florida Current (FC) (blue arrow). The surface FC is dominated by low-salinity water advected from the tropical North Atlantic via the Caribbean and into the Straits of Florida. The Great Bahama Bank sites (plus signs), $118 \mathrm{MC}\left(531 \mathrm{~m}\right.$ depth; $\left.24^{\circ} 35.4^{\prime} \mathrm{N}, 79^{\circ} 16.1^{\prime} \mathrm{W}\right)$ and $125 \mathrm{MC}\left(694 \mathrm{~m}\right.$ depth; $\left.24^{\circ} 45.5^{\prime} \mathrm{N}, 79^{\circ} 17.5^{\prime} \mathrm{W}\right)$, reflect the influence of the FC as well as the relatively salty Santaren Current (red arrow).

mens from the $>250 \mu \mathrm{m}$ size fraction. All three multicore core tops in this study have $>1$ fraction modern radiocarbon, indicating that deposition occurred primarily after 1950 A. D. The one gravity core (79GGC) has a ${ }^{14} \mathrm{C}$ core top age of 200 years [Lund and Curry, 2004], also indicating the presence of bomb radiocarbon, but to a lesser extent than the multicores. Raw radiocarbon ages were converted to calendar ages using CALIB 4.3 [Stuiver et al., 1998], assuming a surface ocean reservoir age of 400 years. Average sedimentation rates for the cores range from 21 to $42 \mathrm{~cm} / \mathrm{kyr}$ (Table 1). We sampled $118 \mathrm{MC}$ and $125 \mathrm{MC}$ every $1 \mathrm{~cm}$, equivalent to time intervals of 24 and 48 years, respectively. 
Table 1. Radiocarbon Ages for Cores KNR166-2-118MC-A, KNR166-2-125MC-D, and KNR166-2-62MC-A

\begin{tabular}{|c|c|c|c|c|c|}
\hline $\begin{array}{l}\text { Sample Depth } \\
\text { Range, cm }\end{array}$ & $\begin{array}{c}\text { Raw }{ }^{14} \mathrm{C} \text { Age, } \\
\text { years }\end{array}$ & $\begin{array}{l}\text { Analytical } \\
\text { Error, years }\end{array}$ & $\begin{array}{c}\text { Calendar Age, } \\
\text { years B.P. }\end{array}$ & $\begin{array}{c}\text { Average Sedimentation } \\
\text { Rate, } \mathrm{cm} / \mathrm{kyr}\end{array}$ & $\begin{array}{l}\text { Average Sampling } \\
\text { Interval, years }\end{array}$ \\
\hline \multicolumn{6}{|c|}{ KNR166-2-118MC-A } \\
\hline $0-1$ & greater than modern ${ }^{\mathrm{a}}$ & NA & 0 & \multirow{3}{*}{42} & \multirow{3}{*}{24} \\
\hline $12-14$ & 635 & 25 & 282 & & \\
\hline $36-37$ & 1320 & 45 & 885 & & \\
\hline \multicolumn{6}{|c|}{ KNR166-2-125MC-D } \\
\hline $0-1$ & greater than modern ${ }^{a}$ & NA & 0 & \multirow{3}{*}{21} & \multirow{3}{*}{48} \\
\hline $10-11$ & 1250 & 30 & 780 & & \\
\hline $27-28$ & 1830 & 35 & 1360 & & \\
\hline \multicolumn{6}{|c|}{$K N R 166-2-62 M C-A$} \\
\hline $0-1$ & greater than modern $^{\mathrm{a}}$ & NA & 0 & \multirow{3}{*}{31} & \multirow{3}{*}{16} \\
\hline $10.5-11.0$ & 920 & 25 & 521 & & \\
\hline $29.0-29.5$ & 1420 & 35 & 955 & & \\
\hline
\end{tabular}

${ }^{\mathrm{a}}$ Core tops contain more radiocarbon than expected in modern samples, indicating contamination with bomb ${ }^{14} \mathrm{C}$ and post1950 A.D. deposition ages. We calibrated the down-core raw ${ }^{14} \mathrm{C}$ values to calendar ages using CALIB 4.3 [Stuiver et al., 1998] and a reservoir age of 400 years. Each date is based on G. ruber from the $>250 \mu \mathrm{m}$ size fraction. Average sedimentation rate is $25 \mathrm{~cm} / \mathrm{kyr}$ and average sampling interval is 20 years for core W167-79GGC. See Lund and Curry [2004] for the W16779GGC age model.

Samples were taken every $0.5 \mathrm{~cm}$ in $62 \mathrm{MC}$ and $79 \mathrm{GGC}$, or every 16 and 20 years, respectively.

\subsection{Sampling Strategy}

[9] To address the potential bias of running $\delta^{18} \mathrm{O}$ and $\mathrm{Mg} / \mathrm{Ca}$ on separate groups of foraminifera, we decided to use one common population of approximately 100 individual G. ruber specimens $(212-250 \mu \mathrm{m}$ size fraction) from each depth interval in 62MC, $118 \mathrm{MC}$, and $125 \mathrm{MC}$. Each sample was sonicated in methanol, siphoned, dried at $70^{\circ} \mathrm{C}$, crushed, weighed, and then split for isotopic and $\mathrm{Mg} / \mathrm{Ca}$ analyses. The crushed sample was evenly distributed on a tray, and split using a fine brush to ensure the subsamples contained approximately equal portions of fine and coarse material. The weight equivalent of $40 \mathrm{G}$. ruber tests was removed and then split into four separate samples for stable isotopic determinations. We set the remainder aside for $\mathrm{Mg} / \mathrm{Ca}$ analyses.

\subsection{Stable Isotopes}

[10] Stable isotope analyses for 79GGC were run on a Finnigan MAT 252 coupled to a Kiel II carbonate device. Analyses for $62 \mathrm{MC}, 118 \mathrm{MC}$, and $125 \mathrm{MC}$ were run on a Finnigan MAT 253 coupled to a Kiel III carbonate device. Calibration to VPDB scale was made using NBS-19 $\left(\delta^{18} \mathrm{O}=\right.$ $-2.20 \%$ and $\delta^{13} \mathrm{C}=1.95 \%$ ). Reproducibility $(1 \sigma)$ of NBS-19 $(\mathrm{n}=461)$ for the MAT 253 system is $\pm 0.08 \%$ o for $\delta^{18} \mathrm{O}$ and $\pm 0.04 \%$ for $\delta^{13} \mathrm{C}$. The $1 \sigma$ values for NBS- 19 on the MAT 252 were $\pm 0.07 \%$ for $\delta^{18} \mathrm{O}$ and $\pm 0.03 \%$ or $\delta^{13} \mathrm{C}(\mathrm{n}>2200$ [Ostermann and Curry, 2000]).

[11] The isotope splits for $62 \mathrm{MC}, 118 \mathrm{MC}$, and $125 \mathrm{MC}$ can be used to determine the degree of sample heterogeneity caused by the splitting procedure. If each isotope split represents the $\delta^{18} \mathrm{O}$ of the sample population, then the variance of the residual $\delta^{18} \mathrm{O}$ at each depth should be similar to the variance of the external standards. Residual values were determined by subtracting the mean $\delta^{18} \mathrm{O}$ value at each depth from the individual measurements. The standard deviation of residual values for the cores is $0.09 \%$, close to the analytical error for NBS-19. The similarity of these statistics indicates that our splitting procedure created subsamples that are representative of the G. ruber population in each sample. A similar comparison is not possible for $79 \mathrm{GGC}$ since the variance of $\delta^{18} \mathrm{O}$ analyses based on multiple measurements of 10 individuals is dominated by sampling rather than analytical uncertainty [Lund and Curry, 2004].

\section{4. $\mathrm{Mg} / \mathrm{Ca}$ Analyses}

[12] The $\mathrm{Mg} / \mathrm{Ca}$ analyses were based on either $50-60$ individual foraminifera (79GGC) or their weight equivalent from a sample of 100 foraminifera $(62 \mathrm{MC}, 118 \mathrm{MC}$, and 125MC). To minimize bias due to matrix effects [Rosenthal et al., 1999], we weighed each $\mathrm{Mg} / \mathrm{Ca}$ split individually to ensure it fell between 150 and $200 \mu \mathrm{g}$. Each sample was cleaned using a sequential three-step process, including clay removal, metal oxide reduction, and organic matter oxidation [Boyle and Keigwin, 1985; Rosenthal et al., 1997]. All samples were run on a Finnigan Element 2 single collector ICP-MS.

[13] Samples were corrected for drift using a $2 \% \mathrm{HNO}_{3}$ blank and a $50 \mathrm{ppm}$ calcium standard. Analytical error was determined using three external standards with $\mathrm{Mg} / \mathrm{Ca}$ ratios of $1.6,3.2$, and $4.8 \mathrm{mmol} / \mathrm{mol}$. The analytical precision $(1 \sigma)$ for each standard was $\pm 0.03(\mathrm{n}=12), \pm 0.04(\mathrm{n}=11)$, and $\pm 0.05 \mathrm{mmol} / \mathrm{mol}(\mathrm{n}=11)$, respectively. $\mathrm{Mg} / \mathrm{Ca}$ ratios for the unknowns were typically in the 4 to $5 \mathrm{mmol} / \mathrm{mol}$ range (Figures 2 and 3). The average precision $(1 \sigma)$ for $\mathrm{Mg} / \mathrm{Ca}$ splits, which reflects both analytical and sample processing uncertainty, is $\pm 0.12 \mathrm{mmol} / \mathrm{mol}(\mathrm{n}=82$ pairs $)$. Poorer precision for the unknowns primarily reflects sample heterogeneity due to the cleaning procedure. $\mathrm{A} \mathrm{Mg} / \mathrm{Ca}$ analytical precision of $\pm 0.05 \mathrm{mmol} / \mathrm{mol}$ translates to an analytical temperature uncertainty of approximately $\pm 0.1^{\circ} \mathrm{C}(1 \sigma)$, whereas the combined analytical and sample processing 

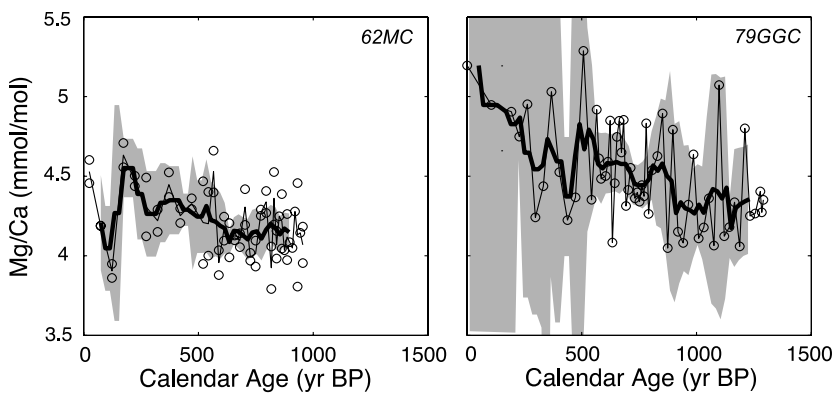

Figure 2. $\mathrm{Mg} / \mathrm{Ca}$ data in $\mathrm{mmol} / \mathrm{mol}$ based on $G$. ruber (white) 212-250 $\mathrm{m}$ for (left) $62 \mathrm{MC}$ and (right) W16779GGC. Circles denote individual $\mathrm{Mg} / \mathrm{Ca}$ analyses. The thin solid line is the average value at each stratigraphic level. The thick solid line represents the 100-year running mean. Shading is the $95 \%$ confidence limit for the 100 -year running mean.

precision $( \pm 0.12 \mathrm{mmol} / \mathrm{mol})$ corresponds to a SST uncertainty of $\pm 0.25^{\circ} \mathrm{C}(1 \sigma)$.

[14] We converted $\mathrm{Mg} / \mathrm{Ca}$ values to sea surface temperature using the general calibration equation of Anand et al. [2003], which is based on sediment trap data from 10 planktonic foraminiferal species $[\mathrm{Mg} / \mathrm{Ca}(\mathrm{mmol} / \mathrm{mol})=$ $\left.0.38 * \exp \left(0.09 * \operatorname{SST}\left({ }^{\circ} \mathrm{C}\right)\right)\right]$. We chose this equation because it is not subject to dissolution biases of core top calibration data sets and is therefore more appropriate for the shallow $(<700 \mathrm{~m})$ core sites discussed in this paper. We used the generalized sediment trap equation because the errors associated with its preexponential and exponential constants are smaller than for the G. ruber-specific calibration [Anand et al., 2003].

[15] Calculated Dry Tortugas core top SST values are approximately 27.5 (62MC) and $28.5^{\circ} \mathrm{C}$ (79GGC) (Figures $4 \mathrm{~b}$ and $4 \mathrm{e}$ ). The annual average sea surface temperature at these sites is $26.9^{\circ} \mathrm{C}$ (Carton and Giese, 2006). On the Great Bahama Bank, the core top $\mathrm{Mg} / \mathrm{Ca}$-derived $\mathrm{SST}$ for $118 \mathrm{MC}$ and $125 \mathrm{MC}$ is $28.0^{\circ}-28.5^{\circ} \mathrm{C}$ (Figures $5 \mathrm{~b}$ and $5 \mathrm{e}$ ), compared to an annual average sea surface temperature of $27.2^{\circ} \mathrm{C}$ (Carton and Giese, 2006). Taking into account the $\pm 1^{\circ} \mathrm{C}(1 \sigma)$ calibration uncertainty [Anand et al., 2003], it appears that foraminiferal $\mathrm{Mg} / \mathrm{Ca}$ produces reasonable absolute temperature estimates for these locations. All four core top values are warmer than observed SSTs, however, a discrepancy that is only amplified if $G$. ruber calcifies closer to $25 \mathrm{~m}$ water depth [Fairbanks et al., 1982; Deuser, 1987], where temperatures are $\sim 0.5^{\circ} \mathrm{C}$ cooler than at the surface (Carton and Giese, 2006).

[16] The calibration based on multiple species may create a warm bias in the SST estimates. If we instead use the calibration for G. ruber, $[\mathrm{Mg} / \mathrm{Ca}(\mathrm{mmol} / \mathrm{mol})=$ $0.34 * \exp \left(0.102 * \mathrm{SST}\left({ }^{\circ} \mathrm{C}\right)\right)$ ] [Anand et al., 2003], the time series become $2^{\circ} \mathrm{C}$ cooler than in the general calibration case, and the core tops fall into better agreement with modern observations. The $\sim 1^{\circ} \mathrm{C}$ offset between $62 \mathrm{MC}$ and $79 \mathrm{GGC}$ SSTs is likely due to the strong temperature gradient along the northern edge of the Florida Current which exposes 79GGC to warmer waters and yields higher
$\mathrm{Mg} / \mathrm{Ca}$-derived SSTs. Spatial SST variability at this scale $(\sim 10 \mathrm{~km})$ is not captured by the $0.5^{\circ} \times 0.5^{\circ}$ gridding of the Carton and Giese (2006) database.

\subsection{The $\delta^{18} \mathrm{O}_{\mathrm{w}}$ Estimates}

[17] We calculated past changes in $\delta^{18} \mathrm{O}_{\mathrm{w}}$ using the isotopic fractionation versus temperature relationship from Bemis et al. [1998] as presented by Lynch-Stieglitz et al. [1999]. Similar results were obtained using the Kim and O'Neil [1997] paleotemperature equation. To evaluate whether the $\delta^{18} \mathrm{O}_{\mathrm{w}}$ values are reasonable, we compare the core top $\delta^{18} \mathrm{O}_{\mathrm{w}}$ to estimates of surface water $\delta^{18} \mathrm{O}_{\mathrm{w}}$ based on modern $\delta^{18} \mathrm{O}_{\mathrm{w}}$-salinity observations. Since the Dry Tortugas sites are heavily influenced by tropical Atlantic surface waters, we used a $\delta^{18} \mathrm{O}_{\mathrm{w}}$ /salinity regression based on data from the open ocean tropical Atlantic $\left[\delta^{18} \mathrm{O}_{\mathrm{w}}(\%)=\right.$ $0.26 * \mathrm{~S}(\mathrm{psu})-8.44$ ] (G. A. Schmidt et al., Global seawater oxygen 18 database, 1999, available at http://www.giss.nasa.gov/data/o18data/, hereinafter referred to as Schmidt et al., 1999). Assuming annual average salinity values of 36.1 near Dry Tortugas (Carton and Giese, 2006), the predicted core top $\delta^{18} \mathrm{O}_{\mathrm{w}}$ is $0.95 \%$, similar to the $62 \mathrm{MC}$ and $79 \mathrm{GGC}$ core top $\delta^{18} \mathrm{O}_{\mathrm{w}}$ values of $0.8 \pm 0.1 \%$ and $1.1 \pm 0.2 \%$, respectively (Figures $4 \mathrm{c}$ and $4 \mathrm{f}$ ). For the Great Bahama Bank sites, the annual average salinity (36.2 (Carton and Giese, 2006)) and subtropical gyre $\delta^{18} \mathrm{O}_{\mathrm{w}} /$ salinity regression $\left[\delta^{18} \mathrm{O}_{\mathrm{w}}(\%)=0.17^{*} \mathrm{~S}(\mathrm{psu})-5.13\right]$ (Schmidt et al., 1999) yield a modern $\delta^{18} \mathrm{O}_{\mathrm{w}}$ of $1.02 \%$. This value is slightly higher than the $0.7 \pm 0.1 \%$ estimate for the $118 \mathrm{MC}$ and 125MC core tops (Figures 5c and 5f).

[18] Although uncertainty in each core top and surface water $\delta^{18} \mathrm{O}_{\mathrm{w}}$ value may account for some of the discrepancy, three of the four core top values underestimate surface water $\delta^{18} \mathrm{O}_{\mathrm{w}}(62 \mathrm{MC}, 118 \mathrm{MC}$, and $125 \mathrm{MC})$. One potential source of systematic error is the use of crushed foraminiferal tests for stable isotope analyses. The $\delta^{18} \mathrm{O}$ values based on crushed foraminifera from $62 \mathrm{MC}$ are consistently $0.2 \%$ lower than $\delta^{18} \mathrm{O}$ values of whole foraminifera from the same samples (Figure 6). We observe no significant offset in $\delta^{13} \mathrm{C}$ between the whole and crushed samples, so it is unlikely due to fractionation of $\mathrm{CO}_{2}$ in the mass spectrometer. Keigwin and Jones [1990] found a similar pattern: the $\delta^{18} \mathrm{O}$ of ground foraminifera was $0.2 \%$ lower than the $\delta^{18} \mathrm{O}$ of whole foraminifera, with no obvious difference in $\delta^{13} \mathrm{C}$ values. This offset is likely due to either variable partition-
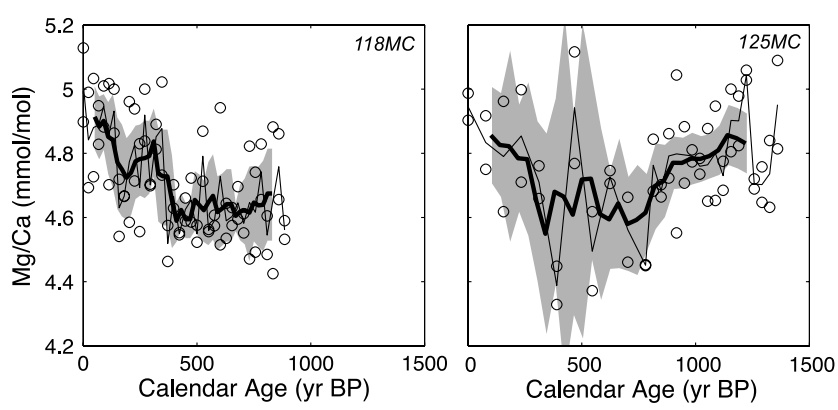

Figure 3. Same as Figure 2 but for the Great Bahama Bank multicores (118MC and $125 \mathrm{MC})$. The $125 \mathrm{MC}$ data were smoothed using a 200-year running mean. 

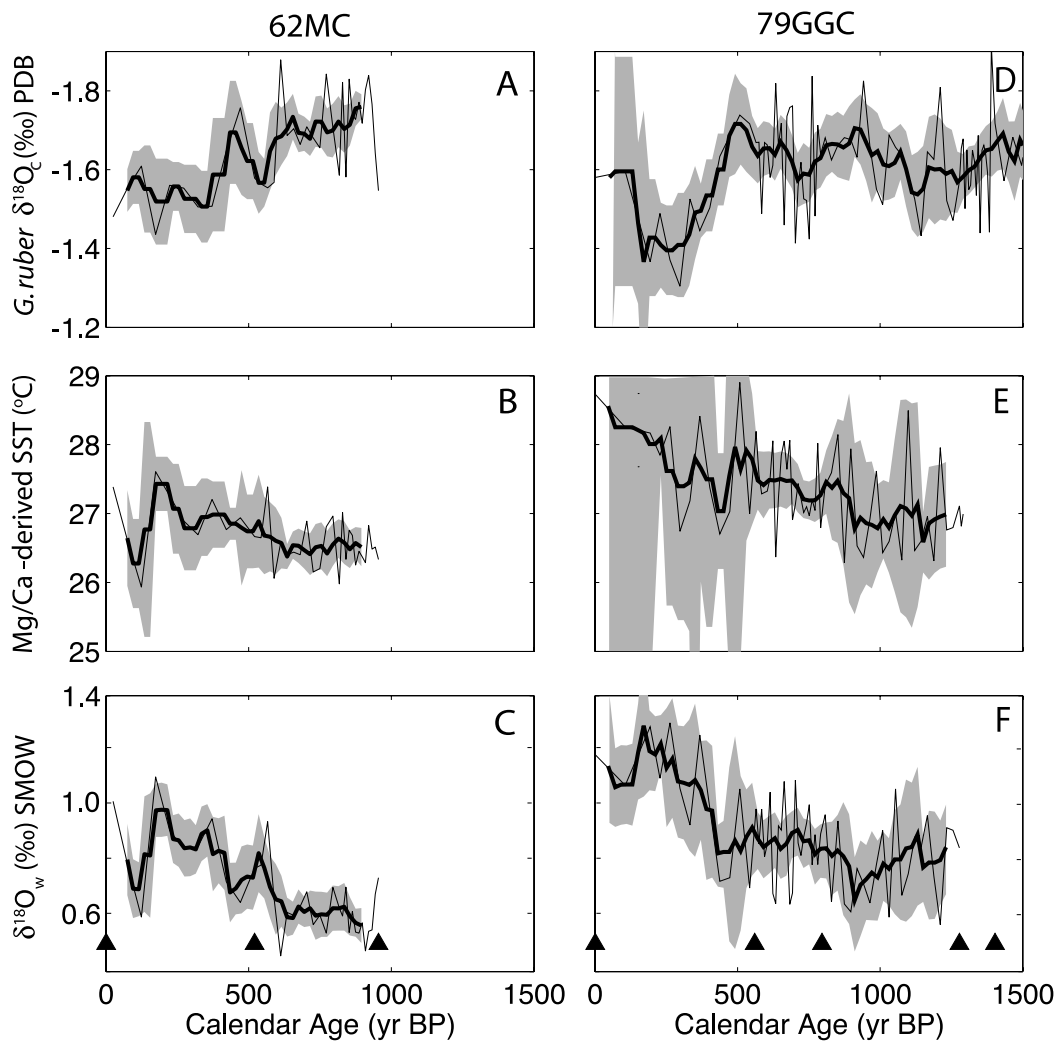

Figure 4. (left) The (a) $\delta^{18} \mathrm{O}_{\mathrm{c}}$, (b) SST, and (c) $\delta^{18} \mathrm{O}_{\mathrm{w}}$ data from KNR166-2-62MC, based on G. ruber (white) $212-250 \mu \mathrm{m}$. (right) The (d) $\delta^{18} \mathrm{O}_{\mathrm{c}}$, (e) SST, and (f) $\delta^{18} \mathrm{O}_{\mathrm{w}}$ data for W167-79GGC. The plotting convention is the same for each of the six subplots, which includes average value at each depth (thin solid line), 100-year running mean (thick solid line), and 95\% confidence limits for the 100-year mean (shaded area). SST estimates are based on $\mathrm{Mg} / \mathrm{Ca}$ analyses and the general temperature calibration of Anand et al. [2003], and $\delta^{18} \mathrm{O}_{\mathrm{w}}$ was calculated using the equation of Bemis et al. [1998]. The $\delta^{18} \mathrm{O}_{\mathrm{w}}$ in each core was highest during the Little Ice Age. Calendar-calibrated radiocarbon dates (triangles) are given in the $\delta^{18} \mathrm{O}_{\mathrm{w}}$ plots. Despite being located only $10 \mathrm{~km}$ apart, $62 \mathrm{MC} \delta^{18} \mathrm{O}_{\mathrm{w}}$ is approximately $0.2 \%$ lower than $79 \mathrm{GGC}$ $\delta^{18} \mathrm{O}_{\mathrm{w}}$. This offset is most likely a function of using crushed foraminiferal tests for $62 \mathrm{MC} \delta^{18} \mathrm{O}$ analyses and whole tests for 79GGC (see section 3). The larger error envelope for $79 \mathrm{GGC}$ is due to the smaller number of foraminifera used for the stable isotope and $\mathrm{Mg} / \mathrm{Ca}$ analyses and fewer replicate $\mathrm{Mg} / \mathrm{Ca}$ measurements.

ing of oxygen isotopes among the products of the calcitephosphoric acid reaction or diffusion of reaction products away from the particle surface associated with the production of $\mathrm{CO}_{2}$ bubbles [Walters et al., 1972; Keigwin and Jones, 1990]. Given that no fractionation occurs when crushed samples are acidified under elevated pressure to prevent foaming, it appears that the fractionation is most likely tied to the rate at which gas evolves during acidification [Walters et al., 1972]. Swart et al. [1991] suggest that production of gas bubbles may encourage isotopic exchange between $\mathrm{CO}_{2}$ and phosphoric acid, thus affecting the average isotopic value of the evolved carbon dioxide.

[19] The apparent grain-size isotopic effect is analogous to temperature-driven changes in the fractionation factor. As the temperature and the reaction rate increase, the fractionation factor $\left({ }^{18} \mathrm{O} /{ }^{16} \mathrm{O}_{\text {calcite }} /{ }^{18} \mathrm{O} /{ }^{16} \mathrm{O}_{\mathrm{CO} 2}\right)$ decreases, leading to lower $\delta^{18} \mathrm{O}$ values [e.g., Swart et al., 1991]. For reasons that remain unclear, faster reaction rates associated with crushed samples apparently lead to a greater proportion of ${ }^{16} \mathrm{O}$ trapped as $\mathrm{CO}_{2}$ and lower $\delta^{18} \mathrm{O}$. Therefore the low $\delta^{18} \mathrm{O}_{\mathrm{c}}$ and $\delta^{18} \mathrm{O}_{\mathrm{w}}$ in $62 \mathrm{MC}$ relative to $79 \mathrm{GGC}$ are most likely a function of crushing the $62 \mathrm{MC}$ samples prior to analysis. If the $\sim 0.2 \%$ offset between the cores were real, it would imply a salinity difference similar to the contrast observed between the subtropical gyre and tropical North Atlantic ( $\sim 1 \mathrm{psu}$ ) (Figure 1). Given that 62MC and 79GGC are located only $10 \mathrm{~km}$ apart, it is highly unlikely that their surface water $\delta^{18} \mathrm{O}_{\mathrm{w}}$ values are offset to this degree. Therefore we conclude that the offset between core top and modern surface water $\delta^{18} \mathrm{O}_{\mathrm{w}}$ can largely be attributed to the use of crushed samples for stable isotope analyses. Since the isotopic fractionation versus temperature relationship from Bemis et al. [1998] is based on whole foraminifera, $0.2 \%$ should be added to the $\delta^{18} \mathrm{O}_{\mathrm{c}}$ data to compensate for the effect of crushing. Applying this correction to $62 \mathrm{MC}$ produces a core top $\delta^{18} \mathrm{O}_{\mathrm{w}}$ value of $1.0 \pm 0.1 \%$, indistin- 

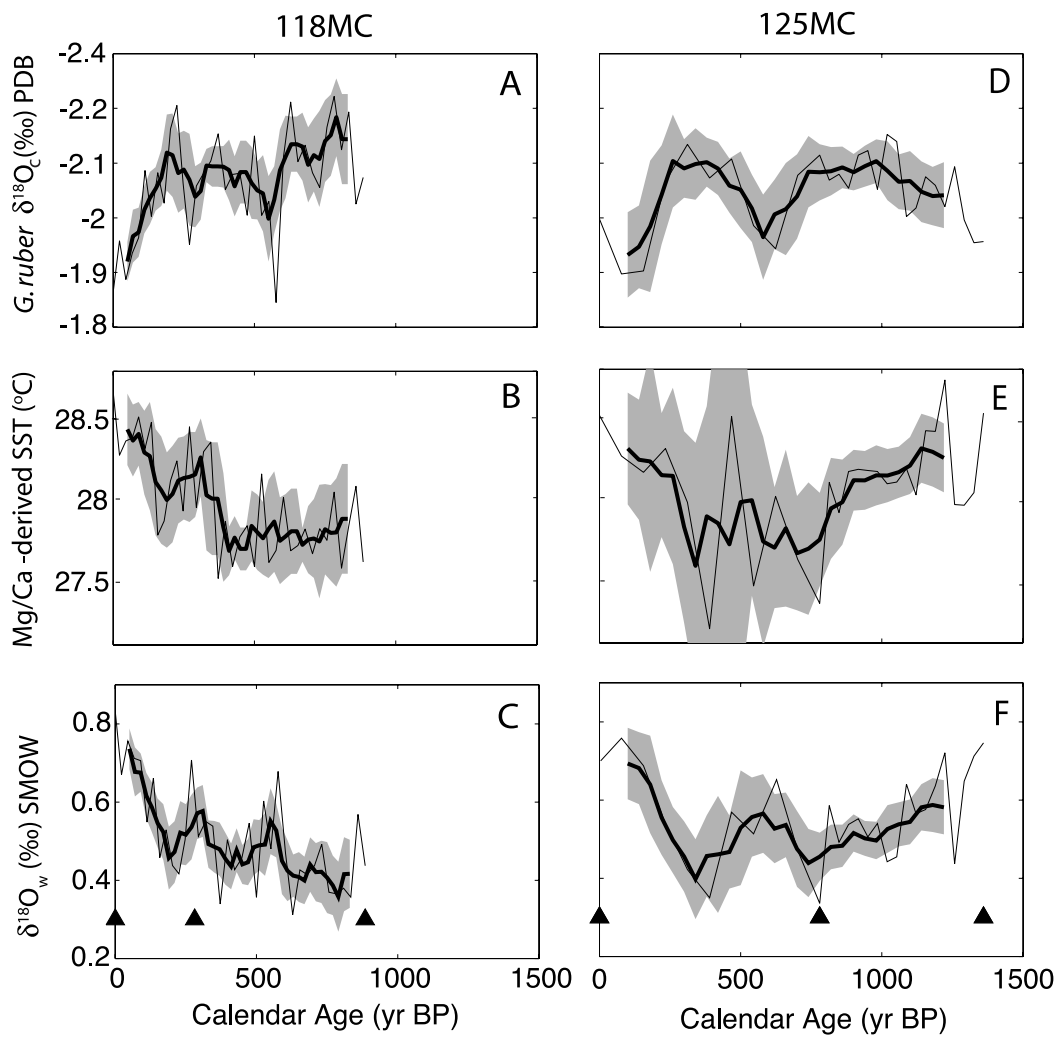

Figure 5. (left) The (a) $\delta^{18} \mathrm{O}_{\mathrm{c}}$, (b) SST, and (c) $\delta^{18} \mathrm{O}_{\mathrm{w}}$, data from KNR166-2-118MC, based on G. ruber (white) $212-250 \mu \mathrm{m}$. (right) The (d) $\delta^{18} \mathrm{O}_{\mathrm{c}}$, (e) SST, and (f) $\delta^{18} \mathrm{O}_{\mathrm{w}}$ data for KNR166-2-125MC. The plotting convention is the same as in Figure 4, except that the running average for $125 \mathrm{MC}$ was calculated using a 200-year window to compensate for the lower sedimentation rate for this core. The wider error envelope for $125 \mathrm{MC}$ reflects the lower data density, even though the smoothing window used was twice as wide as for $118 \mathrm{MC}$. The $\delta^{18} \mathrm{O}_{\mathrm{c}}$ in both cores increased by $0.2 \%$ over the last 300 years. $\mathrm{Mg} / \mathrm{Ca}-$ derived SSTs were lower than today from 700 to 300 years B.P., while those prior to 700 years B.P. approached modern values. The $\delta^{18} \mathrm{O}_{\mathrm{w}}$ data imply that modern surface water at these sites is anomalously salty in the context of the last 1200 years.

guishable from the modern seawater estimate $(0.95 \%$ ). Adding $0.2 \%$ to the $118 \mathrm{MC}$ and $125 \mathrm{MC}$ data yields core top $\delta^{18} \mathrm{O}_{\mathrm{w}}$ values of $0.9 \pm 0.1 \%$, also very similar to the seawater estimate for these sites $(1.02 \%)$ ).

\section{Down-Core Results and Discussion}

\subsection{Surface Water $\delta^{18} \mathrm{O}_{\mathrm{w}}$}

[20] Planktonic $\delta^{18} \mathrm{O}_{\mathrm{c}}$ and SST estimates from 62MC and $79 \mathrm{GGC}$ yield consistent changes in Florida Current $\delta^{18} \mathrm{O}_{\mathrm{w}}$ during the last 1000 years. In 62MC, G. ruber $\delta^{18} \mathrm{O}_{\mathrm{c}}$ increased by approximately $0.2 \%$ over the past 900 years, with the largest change occurring from 400 years B.P. to present (Figure 4a). The $\delta^{18} \mathrm{O}_{\mathrm{c}}$ increase is significant at the 95\% confidence level and implies that Florida Current surface waters became progressively cooler, saltier, or both. $\mathrm{Mg} / \mathrm{Ca}$ analyses of $G$. ruber indicate that SST was stable at $24.5^{\circ} \mathrm{C}$ from 900 to 500 years B.P., and then increased monotonically to $\sim 25.5^{\circ} \mathrm{C}$ by 200 years B.P. (Figure $4 \mathrm{~b}$ ). This SST maximum was followed by an abrupt $1^{\circ} \mathrm{C}$ decrease from 200 to 100 years B.P., and then a steady increase over the past 100 years. Reconciliation of the $\delta^{18} \mathrm{O}_{\mathrm{c}}$ and SST records requires $\delta^{18} \mathrm{O}_{\mathrm{w}}$ variability on the order of $0.4 \%$ (Figure $4 \mathrm{c}$ ). Foraminiferal $\delta^{18} \mathrm{O}_{\mathrm{c}}$ in nearby core 79GGC was nearly constant from 1400 to 500 years B.P. but then increased by $0.2-0.3 \%$ at 500 years B.P. (Figure 4d). Similar to $62 \mathrm{MC}, \mathrm{Mg} / \mathrm{Ca}$-derived SSTs for 79GGC generally increase from 800 to 200 years B.P., although $79 \mathrm{GGC}$ is $0.9^{\circ} \mathrm{C}$ warmer on average over the past 800 years. This difference is similar to the core top offset which reflects the strong SST gradient near Dry Tortugas (section 3).

[21] The 79GGC time series extends the Dry Tortugas $\delta^{18} \mathrm{O}_{\mathrm{w}}$ record to 1400 years B.P. and shows a distinct $0.1-$ $0.2 \%$ increase at 900 years B.P., in addition to the larger $0.4 \%$ o shift at 400 years B.P. (Figure $4 \mathrm{f}$ ). Although the absolute values for the Dry Tortugas $\delta^{18} \mathrm{O}_{\mathrm{w}}$ records are different, the magnitude and timing of their $\delta^{18} \mathrm{O}_{\mathrm{w}}$ variability is nearly identical. The parallel changes in the two records support their fidelity and indicate that each provides a robust signal of $\delta^{18} \mathrm{O}_{\mathrm{w}}$ variability at this location. The $0.2 \%$ offset between $62 \mathrm{MC}$ and $79 \mathrm{GGC}$ is caused by the difference in $\delta^{18} \mathrm{O}_{\mathrm{c}}$ from using whole versus crushed fora- 


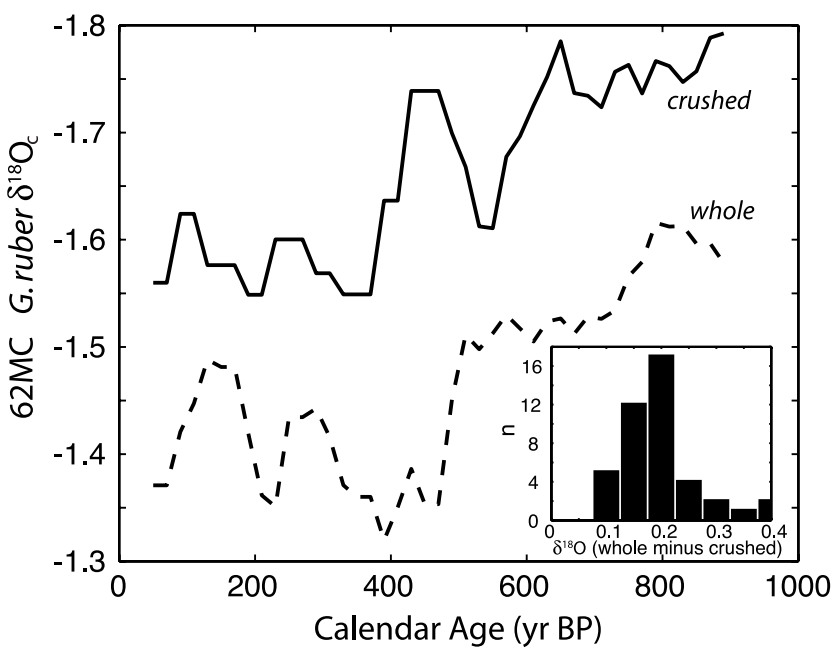

Figure 6. The 100-year running mean $\delta^{18} \mathrm{O}_{\mathrm{c}}$ for whole (dashed) and crushed (solid) foraminifera from 62MC. Inset shows a histogram of whole $\delta^{18} \mathrm{O}_{c}$ minus crushed $\delta^{18} \mathrm{O}_{c}$ at each depth interval. The values based on whole foraminifera are consistently enriched in ${ }^{18} \mathrm{O}$ by $0.2 \%$. This offset may be due to variable isotopic exchange between phosphoric acid and evolved $\mathrm{CO}_{2}$ associated with gas bubble production.

minifera for the stable isotopic analyses in these two cores (section 3).

[22] On the Great Bahama Bank, significant changes in $\delta^{18} \mathrm{O}_{\mathrm{c}}$ and SST occurred during the past millennium, but with different timing than the Dry Tortugas sites. The largest change in $118 \mathrm{MC} \delta^{18} \mathrm{O}_{\mathrm{c}}$ occurred from 200 years B.P. to present (Figure 5a). A similar shift occurred about 100 years earlier in the $125 \mathrm{MC}$ record (Figure 5d). Since $118 \mathrm{MC}$ has better sampling resolution and chronological control than $125 \mathrm{MC}$, the $\delta^{18} \mathrm{O}_{\mathrm{c}}$ increase most likely occurred after 200 years B.P. $\mathrm{Mg} / \mathrm{Ca}$-derived SSTs in $118 \mathrm{MC}$ increased gradually by $0.5^{\circ} \mathrm{C}$ from 500 years B.P. to present (Figure 5b). Core $125 \mathrm{MC}$ extends the Great Bahama Bank SST record to 1400 years B.P. and shows a $\sim 0.5^{\circ} \mathrm{C}$ cooling at 800 years B.P., near the beginning of the LIA, and then a $\sim 0.5^{\circ} \mathrm{C}$ warming at $\sim 300$ years B.P. (Figure $5 \mathrm{e}$ ). The combined $\delta^{18} \mathrm{O}_{\mathrm{c}}$ and SST records require that $\delta^{18} \mathrm{O}_{\mathrm{w}}$ along the Great Bahama Bank increased by $\sim 0.3 \%$ o during the past 200 years (Figures $5 \mathrm{c}$ and $5 \mathrm{f}$ ).

\subsection{Sea Surface Temperatures}

[23] The Great Bahama Bank results are inconsistent with foraminiferal SST estimates from the Sargasso Sea and the magnitude of LIA cooling inferred from Caribbean corals. Rather than increasing after 400 years B.P., SSTs in the Sargasso Sea apparently decreased [Keigwin, 1996]. This discrepancy may be due to the use of different SST proxies: $\delta^{18} \mathrm{O}_{\mathrm{c}}$ for the Sargasso Sea and $\mathrm{Mg} / \mathrm{Ca}$ for the Great Bahama Bank. The data presented here suggest that high Sargasso Sea $\delta^{18} \mathrm{O}_{\mathrm{c}}$ after 200 years B.P. may have been a result of high $\delta^{18} \mathrm{O}_{\mathrm{w}}$ rather than low SSTs. Estimates from Caribbean corals indicate SSTs were $1^{\circ}-3^{\circ} \mathrm{C}$ cooler than today during the coldest LIA intervals [Winter et al., 2000], significantly larger than the cooling along the Great Bahama Bank. The disagreement between the coral and Bahamas SST estimates may be due to the brief ( $\sim 10$ years) time windows covered by the corals and signal smoothing in the foraminiferal records caused by bioturbation.

[24] Interestingly, both Great Bahama Bank and Dry Tortugas SSTs warmed by $\sim 0.5^{\circ} \mathrm{C}$ during the course of the LIA, from about 800 years B.P. to 200 years B.P. (Figure 7). As a result, the $\sim 1.0^{\circ} \mathrm{C}$ cross-current SST gradient remained nearly constant during this time. Prior to 800 years B.P. and after 200 years B.P., however, the cross-current gradient was $1.5^{\circ}-2.0^{\circ} \mathrm{C}$, significantly larger than during the LIA interval. We believe this most likely reflects variable formation of Tortugas eddies, which today can shift SSTs at the $62 \mathrm{MC}$ and $79 \mathrm{GGC}$ core sites by $>3^{\circ} \mathrm{C}$ for months at a time [Fratantoni et al., 1998] (see also APL Ocean Remote Sensing, Gulf of Mexico region, available at http://fermi.jhuapl.edu/avhrr/gm/index.html). Therefore the LIA may have been characterized by reduced Tortugas eddy formation relative to the preceding and subsequent time intervals. This inference is opposite that based only on $\delta^{18} \mathrm{O}_{\mathrm{c}}$ from the Dry Tortugas sites [Lund and Curry, 2004]. The apparent SST differences in 62MC and $79 \mathrm{GGC}$ over the past 600 years (Figure 7) are not significant at the $95 \%$ confidence level (Figures $4 \mathrm{~b}$ and $4 \mathrm{e}$ ).

\section{3. $\mathrm{SST}$ and $\delta^{18} \mathrm{O}_{\mathrm{w}}$ Error Analysis}

[25] We estimated the $95 \%$ confidence limits for SST in two ways (1) based on variance in the raw $\mathrm{Mg} / \mathrm{Ca}$ data only, and (2) based on both the sample variance and calibration uncertainty. In the latter case we used a Monte Carlo approach that accounts for both measurement error and uncertainty in the preexponential and exponential constants for the general $\mathrm{Mg} / \mathrm{Ca}-\mathrm{SST}$ calibration [Anand et al., 2003]. The resulting 95\% confidence limits of approximately $\pm 2^{\circ} \mathrm{C}$ (not shown) are dominated by the calibration uncertainty. Given the down core SST variability can be replicated to within $0.5^{\circ} \mathrm{C}$ (Figure 7), we believe incorporating the absolute calibration uncertainty yields artificially conservative errors for estimating relative changes in SST. The calibration error, which largely reflects uncertainty in the calcification temperatures used for calibration [Anand et al., 2003], appears to be most useful for comparing core top SST estimates with modern observations.

[26] The error envelopes for the $\delta^{18} \mathrm{O}_{\mathrm{w}}$ time series in Figures 4 and 5 are based on Monte Carlo estimates, where at each depth in each core, $\delta^{18} \mathrm{O}_{\mathrm{c}}$ and SST values were randomly sampled from a distribution constrained by the $95 \%$ confidence limits for $\delta^{18} \mathrm{O}_{\mathrm{c}}$ and SST. For example, the error for $62 \mathrm{MC} \delta^{18} \mathrm{O}_{\mathrm{w}}$ (Figure 4c) is based on random data from within the error envelopes in Figures $4 a$ and $4 b$. This approach, which excludes calibration error, yields 95\% confidence limits for $\delta^{18} \mathrm{O}_{\mathrm{w}}$ of approximately $\pm 0.1 \%$. If $\mathrm{Mg} / \mathrm{Ca}-\mathrm{SST}$ calibration error is included, then the uncertainty for $\delta^{18} \mathrm{O}_{\mathrm{w}}$ expands to approximately $\pm 0.4 \%$ o $(95 \%$ confidence limit), similar to that calculated by Schmidt et al. [2004a] for data from the Caribbean.

[27] Whether the $\delta^{18} \mathrm{O}_{\mathrm{w}}$ variability in $62 \mathrm{MC}$ is significant depends on the method used to calculate confidence limits. If we incorporate the calibration error, then the $\delta^{18} \mathrm{O}_{\mathrm{w}}$ signal does not exceed the $95 \%$ confidence level. At the one-sigma 


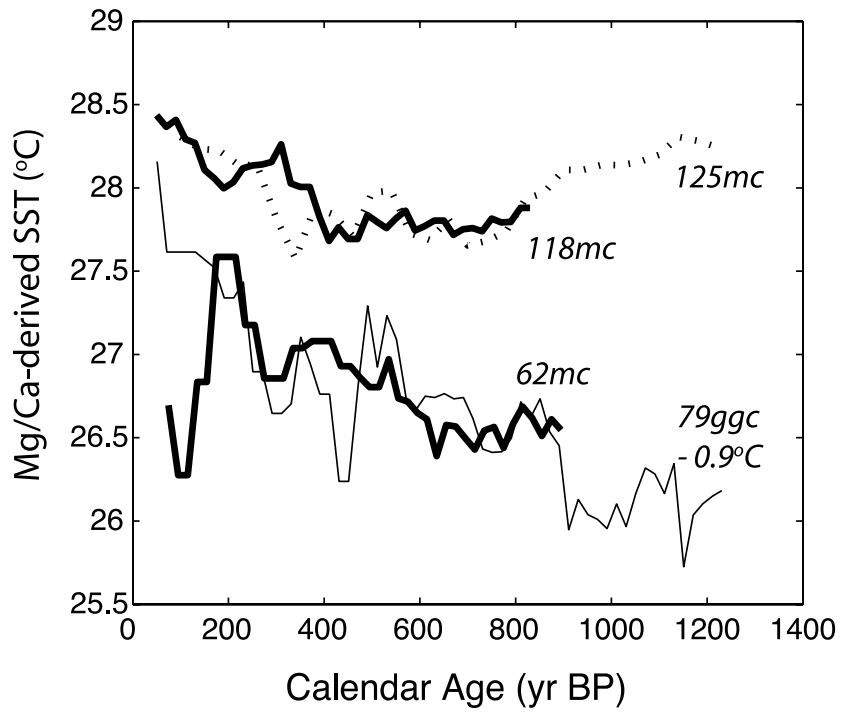

Figure 7. Compilation of smoothed SST records from the Great Bahama Bank (118MC (solid line) and $125 \mathrm{MC}$ (dashed line) and Dry Tortugas (62MC (thick line) and $79 \mathrm{GGC}$ (thin solid). For clarity, the $79 \mathrm{GGC}$ time series was adjusted by $-0.9^{\circ} \mathrm{C}$ (the average offset between $62 \mathrm{MC}$ and $79 \mathrm{GGC}$ from 0 to 800 years B.P.). Cores $118 \mathrm{MC}$ and $62 \mathrm{MC}$ provide the best-constrained SST records for each side of the Florida Current (see confidence limits in Figures 4 and 5). All four time series indicate the surface Florida Current warmed by $0.5^{\circ}-1.0^{\circ} \mathrm{C}$ during the course of the Little Ice Age. The largest cross-current SST gradient occurs prior to and after the Little Ice Age.

level $( \pm 0.2 \%)$, however, the $\delta^{18} \mathrm{O}_{\mathrm{w}}$ increase from 700 to 200 years B.P. is significant (Figure 4c). If we choose to exclude the $\mathrm{Mg} / \mathrm{Ca}-\mathrm{SST}$ calibration error, then smallerscale features, such as high $\delta^{18} \mathrm{O}_{\mathrm{w}}$ at $\sim 200,400$, and 550 years B.P., begin to appear. Similar arguments can be made for $79 \mathrm{GGC}, 118 \mathrm{MC}$, and $125 \mathrm{MC}$. Overall, the $\pm 0.4 \%$ o uncertainty for $\delta^{18} \mathrm{O}_{\mathrm{w}}$ appears to be too conservative for these core sites. For the remainder of this paper, we assume the down core errors for $\delta^{18} \mathrm{O}_{\mathrm{w}}$ (and SST) are better represented by the confidence limits based on sampling uncertainty (Figures 4 and 5). Although this is not entirely satisfactory, the issue can only be resolved through refinement of the $\mathrm{Mg} / \mathrm{Ca}-\mathrm{SST}$ calibration and verification of the records presented here using additional high-resolution $\delta^{18} \mathrm{O}_{\mathrm{w}}$ time series. We are encouraged, however, by the strong similarity of the replicate $\delta^{18} \mathrm{O}_{\mathrm{w}}$ records at both Dry Tortugas and the Great Bahama Bank (section 5.2).

\subsection{Carbonate Ion and ${ }^{13} \mathrm{C}$ Suess Effects}

[28] Great Bahama Bank $\delta^{18} \mathrm{O}_{\mathrm{c}}$ (and hence calculated $\delta^{18} \mathrm{O}_{\mathrm{w}}$ ) may be influenced by decreasing surface water $\mathrm{pH}$ associated with the input of anthropogenic $\mathrm{CO}_{2}$ over the past 200 years. As $\mathrm{pH}$ decreases, the greater proportion of bicarbonate to carbonate ion leads to isotopically heavier dissolved inorganic carbon, since bicarbonate is the more enriched of the two species [Zeebe, 1999]. In laboratory culturing experiments, G. ruber $\delta^{18} \mathrm{O}_{\mathrm{c}}$ varies systematically with $\left[\mathrm{CO}_{3}^{2-}\right]$ by a slope of $-0.002 \pm 0.001 \% \mathrm{o} /(\mu \mathrm{mol} / \mathrm{kg})$ [Spero et al., 1999]. During the last 200 years, surface North Atlantic subtropical gyre dissolved inorganic carbon (DIC) has increased $\sim 60 \mu \mathrm{mol} / \mathrm{kg}$ because of anthropogenic $\mathrm{CO}_{2}$ emissions [Sabine et al., 2004]. Assuming constant nearsurface alkalinity between the LIA and present $(2400 \mu \mathrm{Eq} / \mathrm{kg}$; GEOSECS station 31 ), we estimate that $\left[\mathrm{CO}_{3}^{2-}\right]$ decreased by approximately $40 \mu \mathrm{mol} / \mathrm{kg}$ over this time interval (see http:// geosci.uchicago.edu/ archer/cgimodels/pco2.html), equivalent to a carbonate ion isotope effect on G. ruber $\delta^{18} \mathrm{O}_{\mathrm{c}}$ of $+0.08 \pm 0.04 \%$. Therefore approximately $0.1 \%$ of the $\delta^{18} \mathrm{O}_{\mathrm{w}}$ increase from the LIA to today may be attributed to decreasing surface water $\mathrm{pH}$. If this is true, then the remainder $(0.2 \%)$ reflects increasing salinity of the surface North Atlantic subtropical gyre since the LIA.

[29] Since carbonate ion concentration affects both the oxygen and carbon stable isotopes of foraminiferal calcite, it should be possible to verify the effect of $\mathrm{pH}$ on $\delta^{18} \mathrm{O}_{\mathrm{c}}$ using $\delta^{13} \mathrm{C}_{\mathrm{c}}$. Using a $\left[\mathrm{CO}_{3}^{2-}\right]$ decrease of $40 \mu \mathrm{mol} / \mathrm{kg}$ and a $G$. ruber $\delta^{13} \mathrm{C}_{\mathrm{c}} /\left[\mathrm{CO}_{3}^{2-}\right]$ relationship of $-0.009 \pm 0.001 \%$ o $(\mu \mathrm{mol} / \mathrm{kg})$ [Spero et al., 1999], the expected shift in $\delta^{13} \mathrm{C}_{\mathrm{c}}$ from LIA to present would be $+0.35 \%$, similar to that observed in $118 \mathrm{MC}$ and $125 \mathrm{MC}$ (Figure 8 top). However, if G. ruber $\delta^{13} \mathrm{C}_{\mathrm{c}}$ reliably records $\delta^{13} \mathrm{C}$ of dissolved inorganic carbon $\left(\delta^{13} \mathrm{C}_{\text {DIC }}\right)$, it should reflect not only $\mathrm{pH}$ variability but also the influence of ${ }^{13} \mathrm{C}$-depleted $\mathrm{CO}_{2}$ from fossil fuel and biomass burning (the ${ }^{13} \mathrm{C}$ "Suess effect"). Surface Atlantic $\delta^{13} C_{\text {DIC }}$ decreased by $0.8 \%$ over the past 200 years [Bohm et al., 1996], consistent with model estimates of mixed layer $\delta^{13} \mathrm{C}_{\text {DIC }}$ driven by decreasing $\delta^{13} \mathrm{C}$ of atmospheric $\mathrm{CO}_{2}$ [Francey et al., 1999]. Taking into account both the carbonate ion and Suess effects, the change in G. ruber $\delta^{13} \mathrm{C}_{\mathrm{c}}$ from 200 years B.P. should be approximately $-0.4 \%$, as opposed the observed signal of $+0.3-0.4 \%$.

[30] The $0.8 \%$ offset between predicted and observed ${ }^{13} \mathrm{C}_{\mathrm{c}}$ is either due to real changes in $\delta^{13} \mathrm{C}_{\mathrm{c}}$ or is an artifact of $G$. ruber vital effects. Increasing surface layer $\sum \mathrm{CO}_{2}$ since the LIA would likely enhance biological carbon isotope fractionation and increase $\delta^{13} \mathrm{C}_{\mathrm{c}}$ [Jasper and Hayes, 1990; Hofmann et al., 1999]. An increase in export production of ${ }^{13} \mathrm{C}$-depleted organic matter could also enrich mixed layer ${ }^{13} \mathrm{C}$ of DIC. The situation is further complicated by the tendency of $G$. ruber $\delta^{13} \mathrm{C}_{\mathrm{c}}$ to be lower than ambient seawater $\delta^{13} \mathrm{C}_{\mathrm{DIC}}$. This offset is most likely a function of foraminiferal respiration, metabolic and growth rates, and symbiont photosynthesis, all of which are ecologically sensitive to oceanographic variability [Curry and Matthews, 1981; Spero and Lea, 1993; Russell and Spero, 2000]. Regardless of the exact cause, it is clear G. ruber ${ }^{13} \mathrm{C}_{\mathrm{c}}$ on its own cannot be used to validate the effect of $\mathrm{pH}$ on $\delta^{18} \mathrm{O}_{\mathrm{c}}$.

[31] The problematic nature of using G. ruber $\delta^{13} \mathrm{C}_{\mathrm{c}}$ as a proxy for $\delta^{13} \mathrm{C}_{\mathrm{DIC}}$ is further highlighted by the clear existence of the ${ }^{13} \mathrm{C}$ Suess effect in benthic foraminiferal $\delta^{13} \mathrm{C}$ records from the Great Bahama Bank (Figure 8 bottom). At water depths ranging from 250 to $700 \mathrm{~m}$, four separate benthic time series show anomalous ${ }^{13} \mathrm{C}$ depletion during the past 200 years. The decrease in $\delta^{13} \mathrm{C}_{\mathrm{c}}$ near the core tops is unprecedented during the last millennium and the largest ${ }^{13} \mathrm{C}$ depletion occurs in the shallowest cores 


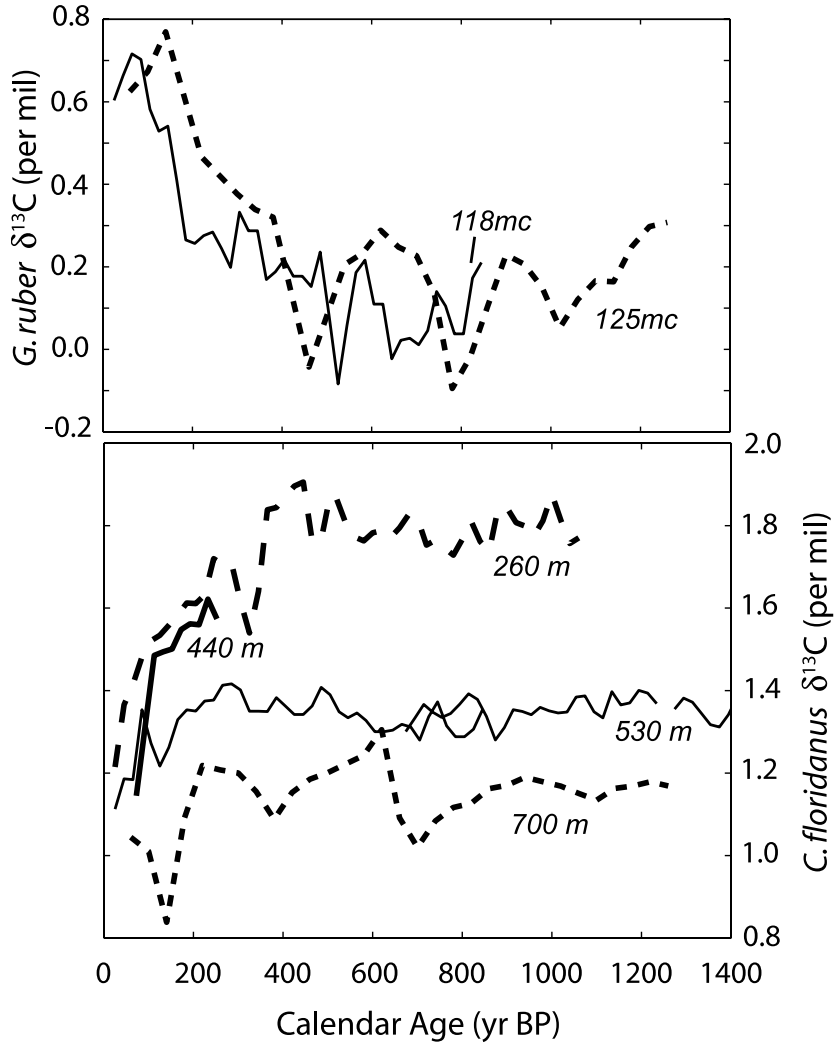

Figure 8. Great Bahama Bank (top) G. ruber $\delta^{13} \mathrm{C}$ and (bottom) C. floridanus $\delta^{13} \mathrm{C}$ over the past 1200 years. C. floridanus has been shown to reliably reflect the $\delta^{13} \mathrm{C}_{\text {DIC }}$ gradient in the North Atlantic subtropical gyre thermocline [Slowey and Curry, 1995]. Both the 118MC (solid line) and $125 \mathrm{MC}$ (dashed line) G. ruber $\delta^{13} \mathrm{C}$ time series are 75 -year running means. The benthic $\delta^{13} \mathrm{C}$ time series are also 75 -year running means, except for $125 \mathrm{MC}$ which was smoothed with a 150 -year window. Raw data are from D. C. Lund and W. B. Curry (manuscript in preparation, 2006). G. ruber $\delta^{13} \mathrm{C}$ increased during the past several hundred years, while the benthic $\delta^{13} \mathrm{C}$ time series show the opposite trend. Although the planktonic $\delta^{13} \mathrm{C}$ signal may reflect decreasing $\mathrm{pH}$, it lacks the ${ }^{13} \mathrm{C}$ Suess effect apparent in the benthic $\delta^{13} \mathrm{C}$ records and other surface mixed layer $\delta^{13} \mathrm{C}$ reconstructions [Bohm et al., 1996; Francey et al., 1999]. We therefore conclude that additional metabolic or ecological factors account for the G. ruber $\delta^{13} \mathrm{C}$ signal.

$(<500 \mathrm{~m})$, consistent with a surface ocean source of ${ }^{13} \mathrm{C}$ depleted $\mathrm{CO}_{2}$. This is the expected response to input of anthropogenic $\mathrm{CO}_{2}$ into midlatitude to high-latitude North Atlantic surface waters and subsequent thermocline ventilation and transport along isopycnals into the subtropical gyre.

\section{Sources of Salinity Variability}

[32] Florida Current $\delta^{18} \mathrm{O}_{\mathrm{w}}$ variability during the last millennium was most likely due to large-scale changes in oceanic precipitation and evaporation. While variable flow of the Mississippi River and altered routing of oceanic currents may have played a minor role, the observed $\delta^{18} \mathrm{O}_{\mathrm{w}}$ signal is too large to be explained by these mechanisms. Instead, southward migration of the Atlantic Hadley circulation during the Little Ice Age, in combination with a mean shift in thermocline $\delta^{18} \mathrm{O}_{\mathrm{w}}$, are the most likely mechanisms responsible for changes in $\delta^{18} \mathrm{O}_{\mathrm{w}}$ near Dry Tortugas and the Great Bahama Bank.

\subsection{Local/Regional $\delta^{18} O_{w}$ Effects}

[33] Input of isotopically light Mississippi River water may have influenced the Dry Tortugas $\delta^{18} \mathrm{O}_{w}$ records, but only to a small extent. Today, the Mississippi River has an annual average flow rate of $0.015 \mathrm{~Sv}$ [Walker et al., 1994] and a $\delta^{18} \mathrm{O}_{\mathrm{w}}$ signature of $-7 \%$ SMOW [Coplen and Kendall, 2000]. Transport in the upper $100 \mathrm{~m}$ of the Florida Current is approximately $9 \mathrm{~Sv}$ [Schmitz and Richardson, $1991]$ with a $\delta^{18} \mathrm{O}_{\mathrm{w}}$ signature of $\sim 0.9 \%$ ( section 3 ).

[34] If the isotopic signature of the oceanic and fluvial end-members is held constant, the $\delta^{18} \mathrm{O}_{\mathrm{w}}$ increase in $62 \mathrm{MC}$ from 700 to 200 years B.P. (0.4\%o) would require Mississippi discharge to change by a factor of 33 (e.g., $0.015 \mathrm{~Sv}$ at 200 years B.P. and $0.5 \mathrm{~Sv}$ at 700 years B.P.). During the 2-month peak of the 1993 flood event, one of the most severe floods of the last century, the Mississippi discharge rate was $0.03 \mathrm{~Sv}$ [Walker et al., 1994], a doubling of the average rate, making even the 1993 flood too small to influence Florida Current $\delta^{18} \mathrm{O}_{\mathrm{w}}$ in a significant way. Given the unrealistic river flows required to create the observed changes in $\delta^{18} \mathrm{O}_{\mathrm{w}}$, and that these flow rates would have to persist for centuries, it is highly unlikely that variability in Mississippi River discharge significantly influenced Florida Current $\delta^{18} \mathrm{O}_{\mathrm{w}}$ during the last millennium.

[35] On the Great Bahama Bank, variable current routing may have affected surface water $\delta^{18} \mathrm{O}_{\mathrm{w}}$ because the $118 \mathrm{MC}$ and $125 \mathrm{MC}$ core sites are located near the confluence of the Santaren and Florida Currents. Today, the Santaren Current supplies on average approximately $2 \mathrm{~Sv}$ of warm, salty water to the main flow of the Florida Current [Atkinson et al., 1995; Leaman et al., 1995]. Lower Santaren Current flow during the LIA would likely result in lower salinity at the core sites. Despite the 0.2 psu difference in salinity on either side of the Florida Current, their $\delta^{18} \mathrm{O}_{\mathrm{w}}$ values are nearly equal (section 3). Therefore reduced flow of the Santaren Current relative to the Florida Current during the LIA would not necessarily lead to lower surface water $\delta^{18} \mathrm{O}_{\mathrm{w}}$ along the Great Bahama Bank. If anything, increased Florida Current salinity during the LIA should lead to saltier conditions at the $118 \mathrm{MC}$ and $125 \mathrm{MC}$ core sites. What is remarkable is that LIA salinities on the GBB are anomalously low relative to core top values, despite the proximity of the cores to the Florida Current (Figure 1).

\subsection{Hadley Cell Migration}

[36] The salinity changes on the Great Bahama Bank were very different than those at Dry Tortugas during the past 1200 years. From 400 to 200 years B.P., when $\delta^{18} \mathrm{O}_{\mathrm{w}}$ was higher than today near Dry Tortugas, it was lower than today on the Great Bahama Bank (Figure 9). Beginning at 200 years B.P., $\delta^{18} \mathrm{O}_{\mathrm{w}}$ increased by $\sim 0.2 \%$ on the Great Bahama Bank, while it decreased by $0.2-0.3 \%$ at Dry 

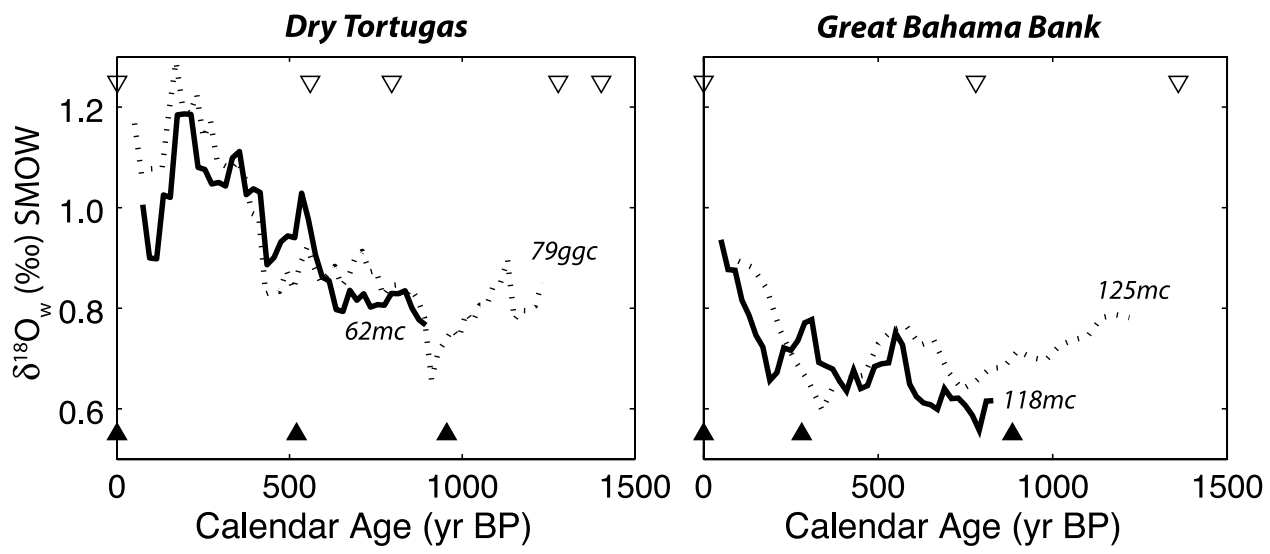

Figure 9. (left) Surface water $\delta^{18} \mathrm{O}_{\mathrm{w}}$ for the Dry Tortugas sites, 0-1400 years B.P. (62MC (solid line) and $79 \mathrm{GGC}$ (dashed line)). The $62 \mathrm{MC}$ data were adjusted by $+0.2 \%$ to account for the effect of crushing on $\delta^{18} \mathrm{O}_{\mathrm{c}}$. Calendar age control points are given as triangles (62MC (solid) and 79GGC (open)). (right) Surface water $\delta^{18} \mathrm{O}_{\mathrm{w}}$ for the Great Bahama Bank sites $118 \mathrm{MC}$ (solid line) and $125 \mathrm{MC}$ (dashed line). The data for both cores were adjusted by $+0.2 \%$ to account for the effect of crushing on $\delta^{18} \mathrm{O}_{\mathrm{c}}$. If Great Bahama Bank surface layer $\left[\mathrm{CO}_{3}^{2-}\right]$ decreased by $60 \mu \mathrm{mol} / \mathrm{kg}$ over the past 200 years, then the $\delta^{18} \mathrm{O}_{\mathrm{w}}$ anomalies relative to core top would be $\sim 0.1 \%$ less than plotted. The smallest offset between the Dry Tortugas and Great Bahama Bank $\delta^{18} \mathrm{O}_{\mathrm{w}}$ records occurred during two intervals: $0-100$ years B.P. and 900-1200 years B.P., coinciding with the modern and Medieval Warm Period, respectively. The largest offset occurred during the peak of the Little Ice Age ( $\sim 100$ to 400 years B.P.).

Tortugas. The largest cross-current difference in $\delta^{18} \mathrm{O}_{\mathrm{w}}$ occurred during the Little Ice Age, while the smallest offsets occurred from approximately 0 to 100 years B.P. and 900 to 1200 years B.P. North-south movement of the Atlantic Hadley circulation is the most likely explanation of the observed $\delta^{18} \mathrm{O}_{\mathrm{w}}$ variability.

[37] Given that Florida Current surface salinity is heavily influenced by $\mathrm{E}-\mathrm{P}$ in the tropical Atlantic, reduced precipitation in this region during the Little Ice Age is the most logical cause of the observed changes. This interpretation is consistent with anomalously dry LIA conditions in the Yucatan Peninsula [Hodell et al., 2005] and northern South America near the Cariaco Basin [Haug et al., 2001]. Comparison of Dry Tortugas $\delta^{18} \mathrm{O}_{\mathrm{w}}$ to the aridity record from the Cariaco Basin suggests a strong climatic link between the two (Figure 10). Cariaco Basin percent Ti, which is proportional to fluvial input, shows a long-term decrease beginning $\sim 600$ years B.P., with distinct minima clustered between 400 and 150 years B.P. [Haug et al., 2001]. The long-term drying of the Cariaco Basin region ended abruptly at 200 years B.P. Overall, the changes observed in $62 \mathrm{MC}$ and $79 \mathrm{GGC} \delta^{18} \mathrm{O}_{\mathrm{w}}$ parallel those in Cariaco Basin percent Ti. One mechanism that could cause this common change is southward ITCZ migration, which would dry the watershed for the Cariaco Basin [Haug et al., 2001], and remotely force increased salinity in the Florida Current.

[38] On an interannual basis, southward migration of the Atlantic ITCZ can be caused by either an increased Atlantic cross-equatorial SST gradient or El Niño conditions in the equatorial Pacific [Chiang et al., 2002]. Even slight $\left(\sim 0.2^{\circ} \mathrm{C}\right)$ cooling of the North Atlantic can force southward migration of the ITCZ, which in turn reduces precipitation in the tropical North Atlantic and creates a positive salinity anomaly in this region [Vellinga et al., 2002; Vellinga and $W u, 2004]$. The Florida Current $\delta^{18} \mathrm{O}_{\mathrm{w}}$ maxima and Cariaco Basin percent $\mathrm{Ti}$ minima from 400 to 150 years B.P. coincide with an interval of unusually cool conditions in several Northern Hemisphere records [Lamb, 1995; deMenocal et al., 2000; Dahl-Jensen et al., 1998; Huang et al., 2000]. This correspondence suggests that LIA cooling in the North Atlantic enhanced the cross-equatorial SST gradient and triggered a southward shift in mean ITCZ position.

[39] Beginning at $\sim 900$ years B.P., $\delta^{18} \mathrm{O}_{\mathrm{w}}$ increased on the Florida Margin and decreased on the Great Bahama Bank, potentially reflecting southward migration of the Hadley cell and increased $\mathrm{E}-\mathrm{P}$ in the tropical Atlantic and decreased E - P in the subtropical gyre. Several paleoclimate records indicate cooling in the North Atlantic region at about this time [Dahl-Jensen et al., 1998; Esper et al., 2002; deMenocal et al., 2000]. The sharp decrease in $\delta^{18} \mathrm{O}_{\mathrm{w}}$ after 200 years B.P. near Dry Tortugas and increase on Great Bahama Bank is consistent with warming since the LIA and an abrupt movement of the Hadley circulation to the north, causing relatively higher salinity in the subtropical gyre and lower salinity in the tropical Atlantic.

\subsection{Surface Ocean Versus Thermocline $\delta^{18} \mathrm{O}_{w}-\mathrm{S}$}

[40] The modern relationship between $\delta^{18} \mathrm{O}_{\mathrm{w}}$ and salinity in the tropical and subtropical Atlantic surface waters is described by a $\delta^{18} \mathrm{O}_{\mathrm{w}} / \mathrm{S}$ slope of approximately $0.2 \%$ per unit salinity change (Figure 11a). In the subtropical gyre, $\delta^{18} \mathrm{O}_{\mathrm{w}}$ is high relative to the tropics since evaporation discriminates against ${ }^{18} \mathrm{O}$. The resulting ${ }^{16} \mathrm{O}$-enriched vapor rains out in the tropics and high-latitude Atlantic. At high latitudes, $\delta^{18} \mathrm{O}$ decreases because of the preferential condensation of ${ }^{18} \mathrm{O}$ at cooler temperatures, making the $\delta^{18} \mathrm{O}_{\mathrm{w}} /$ 


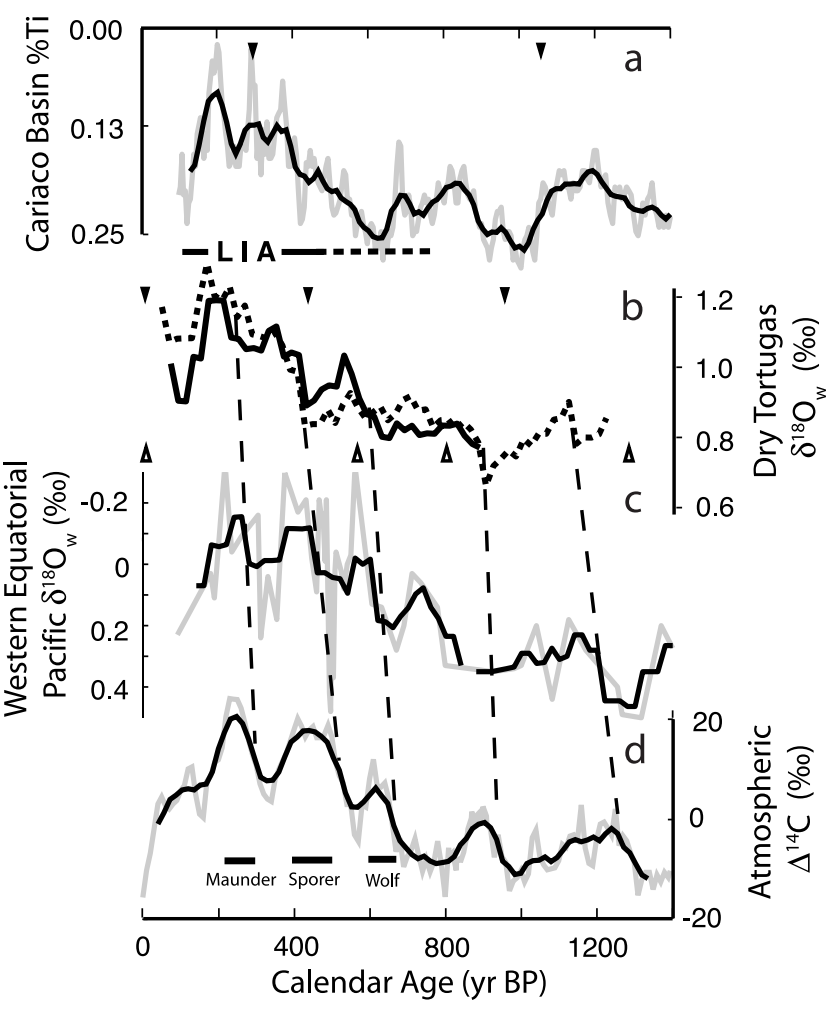

Figure 10. (a) Cariaco Basin percent Ti (raw data (shaded line); 80-year smooth data (solid line)) [Haug et al., 2001]. Lower values imply greater aridity in northern Venezuela. (b) Dry Tortugas $\delta^{18} \mathrm{O}_{\mathrm{w}}$ values (62MC (solid line); 79GGC (dashed line); 100-year smooth). Increasing $\delta^{18} \mathrm{O}_{\mathrm{w}}$ indicates higher surface salinity. The saltiest Dry Tortugas and driest Cariaco Basin conditions occur during the Little Ice Age (LIA). Calendar age control points are noted with triangles. (c) Western equatorial Pacific (WEP) $\delta^{18} \mathrm{O}_{\mathrm{w}}$ (raw data (shaded line); 100-year smooth (solid line)) [Stott et al., 2004]. Note $y$ axis is reversed. In general, the WEP and tropical Atlantic (Dry Tortugas) $\delta^{18} \mathrm{O}_{\mathrm{w}}$ records are anticorrelated. (d) Tree-ring-based reconstruction of atmospheric radiocarbon (10-year bins (shaded line); 80-year smooth (solid line)) [Stuiver et al., 1998]. Common $\Delta{ }^{14} \mathrm{C}_{\mathrm{atm}}$ and tropical Atlantic $\delta^{18} \mathrm{O}_{\mathrm{w}}$ transitions also coincide with $\delta^{18} \mathrm{O}_{\mathrm{w}}$ transitions in the WEP (dashed vertical lines). Dry Tortugas and WEP $\delta^{18} \mathrm{O}_{\mathrm{w}}$ lags $\Delta^{14} \mathrm{C}_{\mathrm{atm}}$ by $50-100$ years. A similar relationship exists with reconstructions of radiocarbon production rate [Bond et al., 2001; Marchal, 2005]. The true phasing remains uncertain given the small lags involved (50-100 years) and the relatively large chronological uncertainties ( $>100$ years).

S slope steeper. Since these waters (up to $\sim 45^{\circ} \mathrm{N}$ ) ventilate the thermocline, the thermocline $\delta^{18} \mathrm{O}_{\mathrm{w}} / \mathrm{S}$ relationship ( $0.5 \%$ o per unit salinity change) is similar to that for the surface high-latitude North Atlantic.

[41] Today, the Dry Tortugas and Bahamas sites differ by $\sim 0.1 \%$ in $\delta^{18} \mathrm{O}_{\mathrm{w}}$ and $\sim 0.2$ in salinity (Figure $11 \mathrm{a}$ ). During the LIA, $\delta^{18} \mathrm{O}_{\mathrm{w}}$ increased by $0.1 \%$ at Dry Tortugas and decreased by $\sim 0.2 \%$ at the Great Bahama Bank. If this was a function of simply moving along the low-latitude $\delta^{18} \mathrm{O}_{\mathrm{w}}-\mathrm{S}$ slope, this would imply LIA salinities of 36.5 at Dry Tortugas and 35.7 at the Bahamas (Figure 11b). This is unrealistic since it requires the surface North Atlantic subtropical gyre to be fresher than the tropical Atlantic (i.e., a reversal of the Hadley cell distribution of $\mathrm{E}-\mathrm{P}$ ). A more reasonable scenario involves southward migration of the Hadley circulation and its associated $\mathrm{E}-\mathrm{P}$ patterns (Figure 11c). In this case, the tropical Atlantic becomes saltier along the $0.2 \%$ slope, but the subtropical gyre becomes fresher through greater influence of ${ }^{18} \mathrm{O}$-depleted surface water from higher latitudes (equivalent to the thermocline $\delta^{18} \mathrm{O}_{\mathrm{w}}-\mathrm{S}$ line). The situation depicted in Figure $11 \mathrm{c}$ allows $\delta^{18} \mathrm{O}_{\mathrm{w}}$ at Great Bahama Bank to be lower than Dry Tortugas and minimizes the LIA salinity difference between the two sites. Although less extreme than the first case, this scenario still requires a salinity gradient the reverse of today.

[42] Surface water $\delta^{18} \mathrm{O}_{\mathrm{w}}$ is not only a function of evaporation and precipitation, but also the $\delta^{18} \mathrm{O}_{\mathrm{w}}$ of water with which it mixes. For the surface North Atlantic, this mixing component is the thermocline. If thermocline $\delta^{18} \mathrm{O}_{\mathrm{w}}$ and salinity varied during the LIA, it would likely be along its modern slope of $0.5 \%$. Since the thermocline dominates the surface layer from a volumetric standpoint, the entire low-latitude surface Atlantic $\delta^{18} \mathrm{O}_{\mathrm{w}} / \mathrm{S}$ relationship would also move along a thermocline slope to retain mass balance [Craig and Gordon, 1965]. In this way, a $0.1 \%$ increase in mean thermocline $\delta^{18} \mathrm{O}_{\mathrm{w}}$ could account for the $0.1 \%$ increase at Dry Tortugas during the LIA (Figure 11d). The thermocline scenario would also require a positive shift in Great Bahama Bank $\delta^{18} \mathrm{O}_{\mathrm{w}}$, however, opposite that observed.

[43] The scenario most consistent with the sign and magnitude of $\delta^{18} \mathrm{O}_{\mathrm{w}}$ variability in our records involves a combination of the thermocline and Hadley circulation models (Figure 11e). Higher mean thermocline $\delta^{18} \mathrm{O}_{\mathrm{w}}$ reduces the implied LIA salinity change at Dry Tortugas and southward migration of the Hadley cell and provides a mechanism for introducing ${ }^{18} \mathrm{O}$-depleted surface waters into the subtropical gyre. This approach avoids the pitfall of a reversed salinity gradient by moving each site in opposite directions along lines with $0.5 \%$ slopes. In fact, the only way to accommodate the opposing changes in $\delta^{18} \mathrm{O}_{\mathrm{w}}$ on either side of the Florida Current is to invoke the influence of high-latitude and thermocline waters. Using today's lowlatitude $\delta^{18} \mathrm{O}_{\mathrm{w}}-\mathrm{S}$ relationship to estimate past changes in salinity yields unreasonable results (Figure 11b). If we use instead the high-latitude slope, then LIA salinities at Dry Tortugas and Great Bahama Bank were nearly equal. This does not mean that salinities in the subtropical gyre and tropical Atlantic were also equal. Today the salinity offset between these regions is on the order of $\sim 1$, whereas the offset between the coring sites is only $\sim 0.3$. During the LIA therefore the salinity gradient between the tropics and subtropical gyre was likely lower than today, but probably not zero.

\subsection{El-Niño Southern Oscillation}

[44] Of course, the North Atlantic does not act independently of the remainder of the climate system. Anomalous 

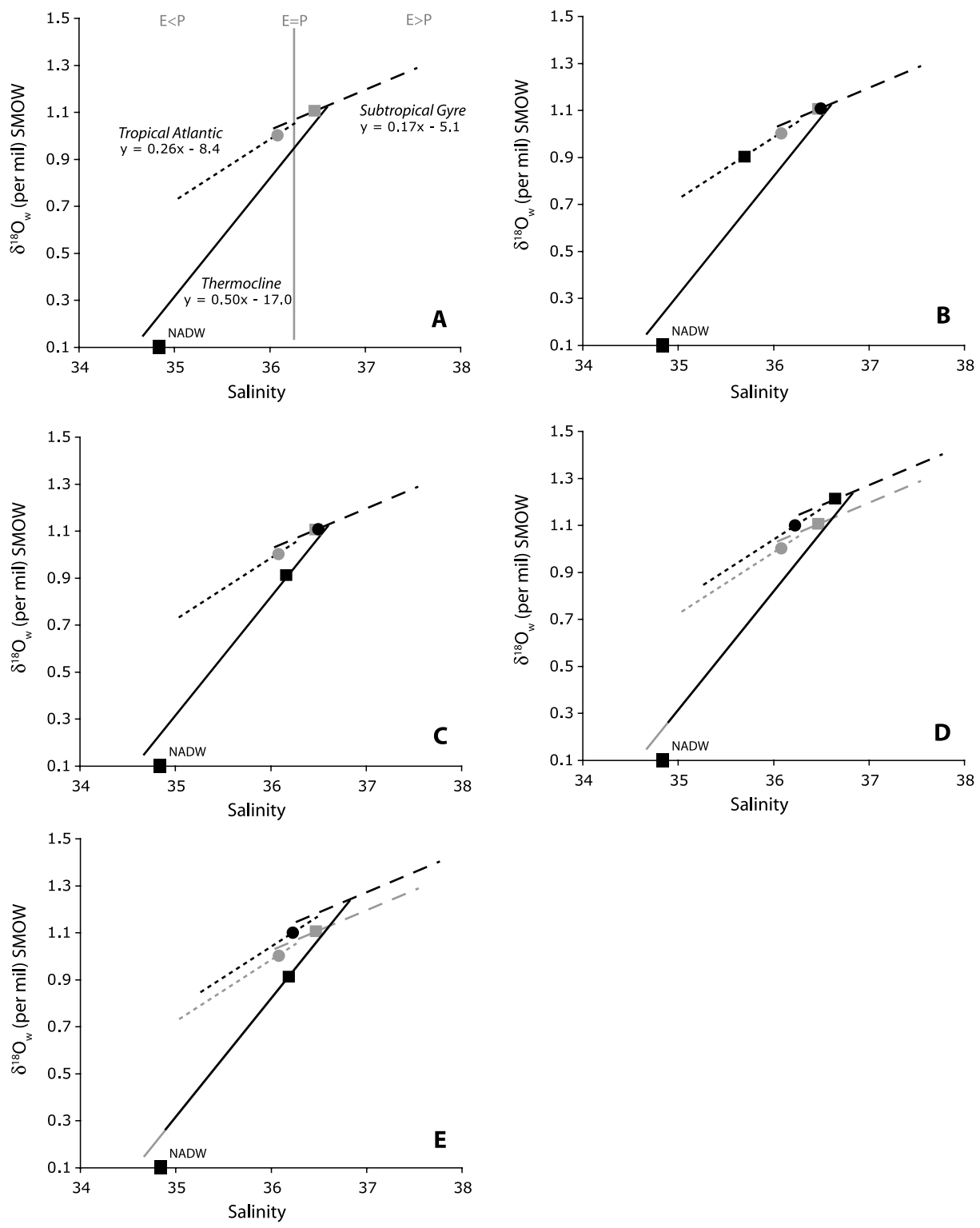

Figure 11. (a) Modern $\delta^{18} \mathrm{O}_{\mathrm{w}}-\mathrm{S}$ regressions for the North Atlantic, including the tropics, subtropical gyre, and thermocline (data from G. A. Schmidt et al., Global seawater oxygen 18 database, 1999, available at http://www.giss.nasa.gov/data/o18data/). Since the thermocline is ventilated at midlatitudes to high latitudes, this line also represents the high-latitude surface North Atlantic. On the basis of modern annual average salinity of 36.1 the Dry Tortugas sites plot along the tropical relationship $\left(\delta^{18} \mathrm{O}_{\mathrm{w}}=0.95\right.$ (shaded circle)) where $\mathrm{E}-\mathrm{P}$ (evaporation minus precipitation) is negative. The Great Bahama Bank sites, with average salinity of 36.2, plot along the subtropical gyre line $\left(\delta^{18} \mathrm{O}_{\mathrm{w}}=1.02\right.$ (shaded square)), where $\mathrm{E}-\mathrm{P}$ is positive. Today's average $\delta^{18} \mathrm{O}_{\mathrm{w}}$-S for North Atlantic Deep Water (NADW) is noted with the solid square [Craig and Gordon, 1965]. (b) Little Ice Age $\delta^{18} \mathrm{O}_{\mathrm{w}}$ values at Dry Tortugas (solid circle) and Great Bahama Bank (solid square). Dry Tortugas values were $\sim 0.1 \%$ heavier than today, while those on the Great Bahama Bank were $\sim 0.2 \%$ lighter. Using the modern low-latitude slopes, this scenario implies the Dry Tortugas sites were saltier than the Bahamas, an unrealistic possibility. (c) Southward Hadley cell migration case (see text). Dry Tortugas values increase along the low-latitude line as before, but now the Bahamas are influenced by a greater proportion of high-latitude ${ }^{18} \mathrm{O}$-depleted water and therefore move along the $0.5 \%$ slope. The LIA salinity values remain reversed but to a lesser extent than the previous scenario. (d) An increase in the mean thermocline $\delta^{18} \mathrm{O}_{\mathrm{w}}$ of $0.1 \%$ moving all the lines upward along the $0.5 \%$ slope, easily accounting for the LIA Dry Tortugas $\delta^{18} \mathrm{O}_{\mathrm{w}}$ (solid circle) but also causing the Bahamas to increase by $0.1 \%$ (solid square), opposite the observed change. (e) A combination of the models in Figures 11c and 11d), where the mean thermocline $\delta^{18} \mathrm{O}_{\mathrm{w}}-\mathrm{S}$ increases and the Hadley circulation migrates southward. This is the most realistic model for the data as it eliminates the pitfall of a reversed salinity gradient. 
atmospheric convection in the eastern equatorial Pacific during El Niño events forces subsidence and decreased precipitation over the tropical North Atlantic [Chiang et al., 2002]. El Niño events also cause the main locus of rainfall to migrate into the central equatorial Pacific, away from its more typical location in the western equatorial Pacific (WEP) (see http://www.cdc.noaa.gov/ENSO). Coral $\delta^{18} \mathrm{O}$ records show a decreased equatorial Pacific zonal SST gradient during the LIA, possibly caused by more frequent El Niño events during this time [Hendy et al., 2002; Cobb et $a l ., 2003]$. If the interannual model can be applied to longer timescales, El Niño-like conditions would lead to decreased precipitation in the northern tropical Atlantic, as is observed, but also in the WEP. Available evidence shows that this did not occur. Low $\delta^{18} \mathrm{O}_{\mathrm{w}}$ in the WEP during the LIA [Stott et al., 2004] is inconsistent with the simple interannual model (Figure 10). Either ENSO played little role in Atlantic ITCZ movement or the MD81 $\delta^{18} \mathrm{O}_{\mathrm{w}}$ record reflects climatic processes other than ENSO.

\subsection{Role of Solar Variability}

[45] Reduced sunspot counts [Eddy, 1976], higher atmospheric $\Delta^{14} \mathrm{C}\left(\Delta^{14} \mathrm{C}_{\mathrm{atm}}\right)$ [Stuiver et al., 1991] and greater ${ }^{10} \mathrm{Be}$ flux [Bard et al., 2000] all imply solar irradiance was lower than today during the LIA. High $\Delta{ }^{14} \mathrm{C}_{\mathrm{atm}}$ during the Maunder, Spörer, and Wolf sunspot minima matches intervals of high Florida Current $\delta^{18} \mathrm{O}_{\mathrm{w}}$ and low western equatorial Pacific $\delta{ }^{18} \mathrm{O}_{\mathrm{w}}$ (Figure 10). The $\delta^{18} \mathrm{O}_{\mathrm{w}}$ records appear to lag $\Delta^{14} C_{\text {atm }}$ by $50-100$ years, assuming surface reservoir ages were similar to modern values over the past 1200 years. A similar lag is observed when comparing $\delta^{18} \mathrm{O}_{\mathrm{w}}$ with modeled estimates of radiocarbon production rate [Bond et al., 2001; Marchal, 2005]. If this lag is correct, then it appears that solar variability paced not only migration of the North Atlantic subpolar front [Bond et al., 2001] but also centennial-scale hydrologic variability in both the tropical Atlantic and Pacific.

[46] Numerical simulations of the evaporation-precipitation $(\mathrm{E}-\mathrm{P})$ response to reduced solar irradiance lack the positive $\mathrm{E}-\mathrm{P}$ anomaly in the tropical North Atlantic and negative $\mathrm{E}-\mathrm{P}$ anomaly in the tropical South Atlantic characteristic of southward ITCZ migration [Rind and Overpeck, 1993]. An imposed $1^{\circ}-2^{\circ} \mathrm{C}$ cooling across the entire North Atlantic is capable of creating the tropical Atlantic E - P dipole pattern, however [Rind and Overpeck, 1993]. Dynamics of the ocean and atmosphere coupling not yet included in solar irradiance models may create very different temperature and $\mathrm{E}-\mathrm{P}$ anomalies. Reduced northward surface heat transport associated with weaker meridi- onal overturning or wind-driven subtropical gyre circulation may provide the cooling necessary to force ITCZ movement. Available paleoclimate evidence for reduced North Atlantic Deep Water production during the LIA is equivocal [Keigwin and Boyle, 2000].

\section{Conclusions}

[47] The surface hydrography of the Florida Current was highly variable during the last millennium. Near Dry Tortugas, salinity increased by $0.8-1.5$ during the course of the Little Ice Age. Similar although larger changes in tropical Atlantic salinity and Northern Hemisphere temperature are observed on glacial-interglacial and millennial timescales [Schmidt et al., 2004a, 2004b]. Thus this pattern of climate variability is not necessarily a manifestation of large continental ice sheets as it can occur under climatic boundary conditions very similar to today. Variable solar irradiance apparently paced shifts in Florida Current salinity during the last millennium, implying the transport of salt into the North Atlantic is sensitive to modest changes in solar forcing on centennial timescales. The lack of evidence for variable Atlantic overturning during the LIA [Keigwin and Boyle, 2000] suggests that southward ITCZ migration and increased Gulf Stream salinity may stabilize changes in North Atlantic Deep Water production, as is predicted by model studies [Vellinga et al., 2002; Vellinga and Wu, 2004].

[48] On the Great Bahama Bank, where surface waters reflect the influence of the North Atlantic subtropical gyre, SST and $\delta^{18} \mathrm{O}_{\mathrm{w}}$ records display different variability than their Dry Tortugas counterparts. Sea surface temperatures decreased by $0.5^{\circ} \mathrm{C}$ at the beginning of the LIA, consistent with the timing of cooling in several Northern Hemisphere temperature records. SSTs increased by $0.5^{\circ} \mathrm{C}$ about 200 years prior to the LIA termination, however, suggesting a more heterogeneous temperature anomaly pattern at the end of the LIA. If $\delta^{18} \mathrm{O}_{\mathrm{w}}$ on the Great Bahama Bank represents primarily salinity rather than anthropogenically driven $\mathrm{pH}$ effects, then surface salinity increased $\sim 0.4$ during the last 200 years, making the modern values the saltiest of the last millennium.

[49] Acknowledgments. We would like to thank Howie Spero, David Lea, Olivier Marchal, Lloyd Keigwin, Delia Oppo, and Jerry McManus for their valuable comments and suggestions. We also thank Dorinda Ostermann, Marti Jeglinski, Paige Cerulli, Simon Thorrold, and Scot Birdwhistle for technical support. We are grateful to the WHOI core lab for sample collection and archiving, the captain and crew of the R/V Knorr, and the Sea Education Association for access to their vessel Westward. This work was supported by NSF grant OCE-0096469.

\section{References}

Anand, P., H. Elderfield, and M. H. Conte (2003), Calibration of $\mathrm{Mg} / \mathrm{Ca}$ thermometry in planktonic foraminifera from a sediment trap time series, Paleoceanography, 18(2), 1050, doi:10.1029/2002PA000846.

Atkinson, L. P., T. Berger, P. Hamilton,

E. Waddell, K. Leaman, and T. N. Lee (1995),

Current meter observations in the Old Bahama
Channel, J. Geophys. Res., 100, 85558560

Bard, E., G. Raisbeck, F. Yiou, and J. Jouzel (2000), Solar irradiance during the last 1200 years based on cosmogenic nuclides, Tellus, Ser. B, 52, 985-992.

Bemis, B. E., H. J. Spero, J. Bijma, and D. W. Lea (1998), Reevaluation of the oxygen isoto- pic composition of planktonic foraminifera: Experimental results and revised paleotemperature equations, Paleoceanography, 13 , $150-160$.

Bohm, F., M. M. Joachimski, H. Lehnert, G. Morgenroth, W. Kretschmer, J. Vacelet, and W. C. Dullo (1996), Carbon isotopic records from extant Caribbean and South 
Pacific sponges: Evolution of $\delta^{13} \mathrm{C}$ in surface water DIC, Earth Planet. Sci. Lett., 139, $291-$ 303.

Bond, G., B. Kromer, J. Beer, R. Muscheler, M. N. Evans, W. Showers, S. Hoffmann, R. Lotti-Bond, I. Hajdas, and G. Bonami (2001), Persistent solar influence on North Atlantic climate during the Holocene, Science, 294, 2130-2136.

Boyle, E. A., and L. D. Keigwin (1985), Comparison of Atlantic and Pacific paleochemical records for the last 250,000 years: Changes in deep ocean circulation and chemical inventories, Earth Planet. Sci. Lett., 76, 125-150.

Bradley, R. S., and P. D. Jones (1993), Little Ice Age summer temperature variations: Their nature and relevance to recent global warming trends, Holocene, 3, 367-376.

Chiang, J. C. H., Y. Kushnir, and A. Giannini (2002), Deconstructing Atlantic Intertropical Convergence Zone variability: Influence of the local cross-equatorial sea surface temperature gradient and remote forcing from the eastern equatorial Pacific, J. Geophys. Res., 107(D1), 4004, doi:10.1029/2000JD000307.

Chinn, T. J. (1996), New Zealand glacier responses to climate change of the past century, N. Z. J. Geol. Geophys., 39, 415-428.

Cobb, K. M., C. D. Charles, H. Cheng, and R. L. Edwards (2003), El Niño/Southern Oscillation and tropical Pacific climate during the last millennium, Nature, 424, 271-276.

Coplen, T. B., and C. Kendall (2000), Stable hydrogen and oxygen isotope ratios for selected sites of the U. S. Geological Survey's NASQAN and Benchmark Surface-water Networks, U. S. Geol. Surv. Open File Rep., $00-160$

Craig, H. and L. I. Gordon (1965), Isotopic oceanography: Deuterium and oxygen 18 variations in the ocean and marine atmosphere, in Symposium on Marine Geochemistry, Occas. Publ. 3, pp. 277-374, Grad. Sch. of Oceanogr., Univ. of R.I., Kingston.

Curry, W. B., and R. K. Matthews (1981), Equilibrium ${ }^{18} \mathrm{O}$ fractionation in small size planktic foraminifera: Evidence from recent Indian Ocean sediments, Mar. Micropaleontol., 6, 327-337.

Dahl-Jensen, D., K. Mosegaard, N. Gundestrup, G. D. Clow, S. J. Johnsen, A. W. Hansen, and N. Balling (1998), Past temperatures directly from the Greenland ice sheet, Science, 282, 268-271.

deMenocal, P., J. Ortiz, T. Guilderson, and M. Sarnthein (2000), Coherent high- and lowlatitude variability during the Holocene warm period, Science, 288, 2198-2202.

Denton, G. H., and W. Karlén (1973), Holocene climatic variations: Their pattern and possible cause, Quat. Res., 3, 155-205.

Deuser, W. G. (1987), Seasonal variations in isotopic composition and deep-water fluxes of the tests of perennially abundant planktonic foraminifera of the Sargasso Sea: Results from sediment-trap collections and their paleoceanographic significance, J. Foraminiferal Res., 17, 14-27.

Druffel, E. M. (1982), Banded corals: Changes in oceanic carbon-14 during the Little Ice Age, Science, 218, 13-19.

Eddy, J. M. (1976), The Maunder Minimum, Science, 192, 1189-1202.

Esper, J., E. R. Cook, and F. H. Schweingruber (2002), Low-frequency signals in long treering chronologies for reconstructing past temperature variability, Science, 295, 22502253.
Fairbanks, R. G., M. Sverdlove, R. Free, P. H Wiebe, and A. W. H. Bé (1982), Vertical distribution and isotopic fractionation of living planktonic foraminifera from the Panama Basin, Nature, 298, 841-844.

Francey, R. J., C. E. Allison, D. M. Etheridge, C. M. Trudinger, I. G. Enting, M. Leuenberger, R. L. Langenfelds, E. Michel, and L. P. Steele (1999), A 1000-yr high precision record of $\delta^{13} \mathrm{C}$ in atmospheric $\mathrm{CO}_{2}$, Tellus, Ser. B, 51, $170-193$.

Fratantoni, P. S., T. N. Lee, G. P. Podesta, and F. Muller-Karger (1998), The influence of Loop Current perturbations on the formation and evolution of Tortugas eddies in the southern Straits of Florida, J. Geophys. Res., 103, $24,759-24,779$

Grove, J. M. (1988), The Little Ice Age, 498 pp., Methuen, New York.

Haug, G., K. A. Hughen, D. M. Sigman, L. C. Peterson, and U. Rohl (2001), Southward migration of the ITCZ through the Holocene, Science, 293, 1304-1308.

Hendy, E. J., M. K. Gagan, C. A. Alibert, M. T. McCulloch, J. M. Lough, and P. J. Isdale (2002), Abrupt decrease in tropical Pacific sea surface salinity at end of Little Ice Age, Science, 295, 1511-1514.

Hodell, D. A., M. Brenner, J. H. Curtis, R. Medina-Gonzalez, E. Ildefonso-Chan Can, A. Albornaz-Pat, and T. P. Guilderson (2005), Climate change on the Yucatan Peninsula during the Little Ice Age, Quat. Res., 63, 109-121.

Hofmann, M., W. S. Broecker, and J. LynchStieglitz (1999), Influence of a $\left[\mathrm{CO}_{2}(\mathrm{aq})\right]$ dependent biological $\mathrm{C}$-isotope fractionation on glacial ${ }^{13} \mathrm{C} /{ }^{12} \mathrm{C}$ ratios in the ocean, Global Biogeochem. Cycles, 13(4), 873-883.

Huang, S., H. N. Pollack, and P. Shen (2000), Temperature trends over the past five centuries reconstructed from borehole temperatures, Nature, 403, 756-758.

Jasper, J. P., and J. M. Hayes (1990), A carbon isotope record of $\mathrm{CO}_{2}$ levels during the late Quaternary, Nature, 347, 462-464.

Keigwin, L. D. (1996), The Little Ice Age and Medieval Warm Period in the Sargasso Sea, Science, 274, 1504-1508.

Keigwin, L., and E. A. Boyle (2000), Detecting Holocene changes in thermohaline circulation, Proc. Natl. Acad. Sci. U. S. A., 97, 13431346.

Keigwin, L. D., and G. A. Jones (1990), Deglacial climatic oscillations in the Gulf of California, Paleoceanography, 5, 1009-1023.

Kim, S. T., and J. O'Neil (1997), Equilibrium and non-equilibrium oxygen isotope effects in synthetic carbonates, Geochim. Cosmochim. Acta., 61, 3461-3475.

Lamb, H. (1995), Climate, History and the Modern World, 2nd ed., Routledge, Boca Raton, Fla.

Leaman, K. D., P. S. Vertes, L. P. Atkinson, T. N. Lee, P. Hamilton, and E. Waddell (1995), Transport, potential vorticity, and current/temperature structure across Northwest Providence and Santaren Channels and the Florida Curren off Cay Sal Bank, J. Geophys. Res., 100, $8561-8569$

Levitus, S., R. Burgett, and T. P. Boyer (1994), World Ocean Atlas 1994, vol. 3, Salinity, NOAA Atlas NESDIS 3, 111 pp., NOAA, Silver Spring, Md.

Lohmann, G. (2003), Atmospheric and oceanic freshwater transport during weak Atlantic overturning circulation, Tellus, Ser. A, 55 , $438-449$.
Lund, D. C., and W. B. Curry (2004), Late Holocene variability in Florida Current surface density: Patterns and possible causes, Paleoceanography, 19, PA4001, doi:10.1029 2004PA001008.

Lynch-Stieglitz, J., W. B. Curry, and N. Slowey (1999), A geostrophic estimate for the Florida Current from the oxygen isotope composition of benthic foraminifera, Paleoceanography, 14, 360-373.

Mann, M. E., R. S. Bradley, and M. K. Hughes (1999), Northern Hemisphere temperatures during the past millennium: Inferences, uncertainties, and limitations, Geophys. Res. Lett. 26, 759-762.

Marchal, O. (2005), Optimal estimation of atmospheric ${ }^{14} \mathrm{C}$ production over the Holocene: $\mathrm{Pa}-$ leoclimate implications, Clim. Dyn., 24, 7188

Mashiotta, T. A., D. W. Lea, and H. J. Spero (1999), Glacial-interglacial changes in Subantarctic sea surface temperature and $\delta^{18} \mathrm{O}$-water using foraminiferal $\mathrm{Mg}$, Earth Planet Sci. Lett., 170, 417-432.

Ostermann, D. R., and W. B. Curry (2000), Calibration of stable isotopic data: An enriched $\delta^{18} \mathrm{O}$ standard used for source gas mixing detection and correction, Paleoceanography, 15 $353-360$.

Rind, D., and J. Overpeck (1993), Hypothesized causes of decade- to century-scale climate variability: Climate model results, Quat. Sci. Rev., 12, 357-374

Rosenthal, Y., E. A. Boyle, and L. Labeyrie (1997), Last glacial maximum paleochemistry and deepwater circulation in the Southern Ocean: Evidence from foraminiferal cadmium, Paleoceanography, 12, 787-796.

Rosenthal, Y., M. P. Field, and R. M. Sherrell (1999), Precise determination of element/cadmium ratios in calcareous samples using sector field inductively coupled plasma mass spectrometry, Anal. Chem., 71, 3248-3253.

Russell, A. D., and H. J. Spero (2000), Field examination of the oceanic carbonate ion effect on stable isotopes in planktonic foraminifera, Paleoceanography, 15, 43-52.

Sabine, C. L., et al. (2004), The oceanic sink for anthropogenic $\mathrm{CO}_{2}$, Science, 305, 367-371.

Schmidt, M. W., H. J. Spero, and D. W. Lea (2004a), Links between salinity variation in the Caribbean and North Atlantic thermohaline circulation, Nature, 428, 160-163.

Schmidt, M. W., M. J. Vautravers, and H. J. Spero (2004b), Gulf Stream salinity variation during MIS 3 and its link to D-O cycles, Eos Trans. AGU, 85(47), Fall Meet. Suppl., Abstract PP44A-06.

Schmitz, W. J., and P. Richardson (1991), On the sources of the Florida Current, Deep Sea Res. Part A, 38, s379-s409.

Slowey, N. C., and W. B. Curry (1995), Glacial-interglacial differences in circulation and carbon cycling within the upper western North Atlantic, Paleoceanography, 10, $715-732$.

Spero, H. J., and D. W. Lea (1993), Intraspecific stable isotope variability in the planktic foraminifera Globigerinoides sacculifer: Results from laboratory experiments, Mar. Micropaleontol., 22, 221-234.

Spero, H. J., J. Bijma, D. W. Lea, and A. D Russell (1999), Deconvolving glacial ocean carbonate chemistry from the planktonic foraminifera carbon isotope record, in Reconstructing Ocean History: A Window Into the Future, edited by F. Abrantes and A. Mix, pp. 329342, Springer, New York. 
Stott, L., K. Cannariato, R. Thunnell, G. H. Haug, A. Koutavas, and S. Lund (2004), Decline of surface temperature and salinity in the western tropical Pacific Ocean in the Holocene epoch, Nature, 431, 56-59.

Stuiver, M., T. F. Braziunas, B. Becker, and B. Kromer (1991), Climatic, solar, oceanic and geomagnetic influences on late-glacial and Holocene atmospheric ${ }^{14} \mathrm{C} /{ }^{12} \mathrm{C}$ change, Quat. Res., 35, 1-24.

Stuiver, M., P. J. Reimer, E. Bard, J. W. Beck, G. S. Burr, K. A. Hughen, B. Kromer, F. G. McCormac, J. van der Plicht, and M. Spurk (1998), INTCAL98 radiocarbon age calibration 24,000-0 cal BP, Radiocarbon, 40, $1041-1083$

Swart, P. K., S. J. Burns, and J. J. Leder (1991), Fractionation of the stable isotopes of oxygen and carbon dioxide during the reaction of calcite with phosphoric acid as a function of temperature and technique, Chem. Geol., 86, 89-96.
Thompson, L. G. (1995), Ice core evidence from Peru and China, in Climate Since A. D. 1500, edited by R. S. Bradley and P. D. Jones, pp. 517-548, Routledge, Boca Raton, Fla.

Vellinga, M., and P. Wu (2004), Low-latitude freshwater influence on centennial-scale variability of the Atlantic thermohaline circulation, J. Clim., 17, 4498-4511.

Vellinga, M., R. A. Wood, and J. M. Gregory (2002), Processes governing the recovery of a perturbed thermohaline circulation in HadCM3, J. Clim., 15, 764-780.

Waliser, D. E., and C. Gautier (1993), A satellitederived climatology of the ITCZ, J. Clim., 6, $2162-2174$.

Walker, N. D., L. J. Rouse, G. S. Fargion, and D. C. Biggs (1994), The Great Flood of summer 1993: Mississippi River discharge studied, Earth Space, 7(3), 11-14.

Walters, L. J., G. E. Claypool, and P. W Choquette (1972), Reaction rates and $\delta^{18} \mathrm{O}$ variations for the carbonate-Phosphoric acid preparation method, Geochim. Cosmochim. Acta, 36, 129-140.

Winter, A., H. Ishioroshi, T. Watanabe, T. Oba, and J. Christy (2000), Caribbean sea surface temperatures: Two-to-three degrees cooler than present during the Little Ice Age, Geophys. Res. Lett., 27, 3365-3368.

Zeebe, R. E. (1999), An explanation of the effect of seawater carbonate concentration on foraminiferal oxygen isotopes, Geochim. Cosmochim. Acta, 63, 2001-2007.

W. Curry, Department of Geology and Geophysics, Woods Hole Oceanographic Institution, MS 24, Woods Hole, MA 02543, USA.

D. C. Lund, Division of Geological and Planetary Sciences, California Institute of Technology, MS 100-23, Pasadena, CA 91125, USA. (dlund@gps.caltech.edu) 